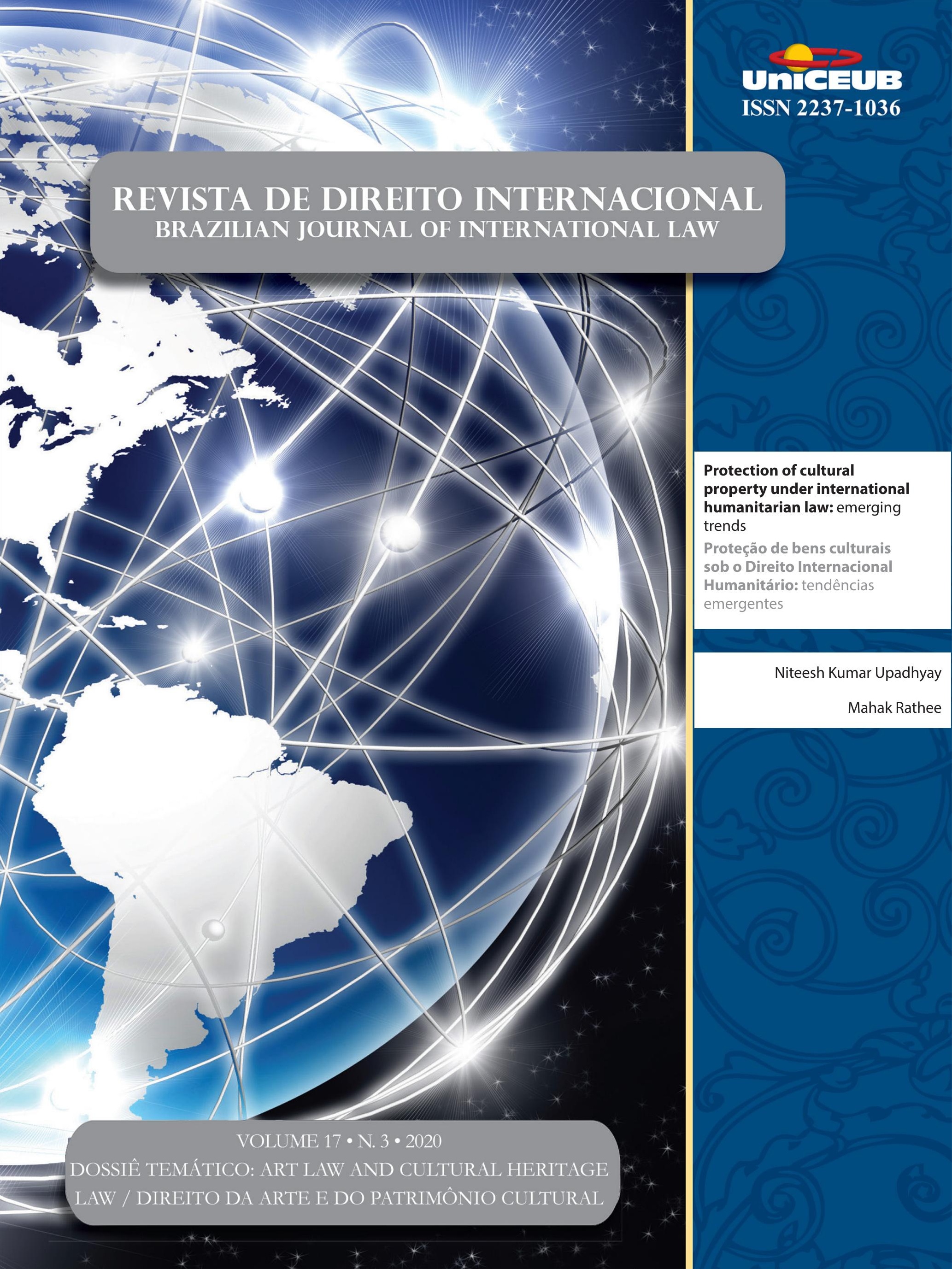




\section{Sumário}

EDITORIAL .20

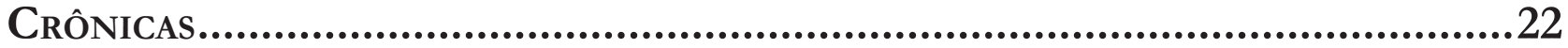

O COSTUME INTERNACIONAL COMO REFORÇO DA OBJEÇÃO BRASILEIRA À CLÁUSULA DO TRATAMENTO JUSTO E EQUITATIVO .24

Leonardo Vieira Arruda Achtschin

O PROCESSO LEGISLATIVO COMO GARANTIA PARA A OBTENÇÃo DO CONSENTIMENTO PRÉVIO DAS COMUnidades quilombolas de AlCÂNTARa

Gabriel de Oliveira Borba

Dossiê temático: Art Law and Cultural Heritage law / Direito da Arte e do Patrimônio cultural - Panorama Geral

Peoples' heritage or States' heritage? sovereignty in the UNESCO mechanism for THE SAFEGUARDING OF INTANGIBLE CULTURAL HERITAGE.

Aliki Gkana

The IMPACT OF THE UNESCO AND UNIDROIT CONVENTIONS AND THE EU DIRECTIVES ON THE INTERNATIONAL ART MARKET: AN ANALYSIS FIFTY YEARS AFTER THE INTRODUCTION OF THE OBLIGATION TO RETURN STOLEN OR ILLEGALLY EXPORTED CULTURAL GOODS 61

Geo Magri

Três pautas em destaque na agenda de diversidade Cultural da Unesco: Ambiente digiTAL, TRATAMENTO PREFERENCIAL E PARTICIPAÇÃO DA SOCIEDADE CIVIL............................76

Danilo Júnior de Oliveira, Maria Carolina Vasconcelos Oliveira e Ana Paula do Val

A 100 YEARS INSTITUTIONALIZED CULTURAL HERITAGE PROTECTION: FROM THE INSTITUTIONALIZED INTERNATIONAL COOPÉRATION INTELLECTUELLE TO THE HUMAN RIGHT TO CULTURAL HERITAGE

Lando Kirchmair 


\section{Aspectos Metodológicos do Direito da Arte e do Patrimônio}

Cultural

A proteção do PATrimônio CULTURAL EM NOVAS PERSPECTIVAS: ESTUdo COMPARAdo ENTRE A Kulturgutschutzgesetz e a Holocaust Expropriated Art Recovery Act of 2016.....111 Ardyllis Alves Soares

ArT-RELATED DispUTES AND ADR METHODS 127 Maria Beatrice Deli e Veronica Proietti

Due Diligence in Art Law and Cultural Heritage Law 150 Lisiane Feiten Wingert Ody

The Reception of Droit de Suite in International Law: Diagnosis and Remedy .... 170 Mickael R. Viglino

Direito da Arte e do Patrimônio Cultural: do Regional ao Local ....... 188

Câmara Cascudo e o legal Design - A Visualidade do Direito entre Provincianismo e GlobalizaÇão 190 Marcilio Toscano Franca Filho

A política da União Europeia no turismo: O turismo cultural e a sustentabilidade do PATRIMONNIO INDUSTRIAL PARA INTEGRAÇÃO DO BLOCO EUROPEU

Maraluce Maria Custódio e Fernando Barotti dos Santos

Diálogo entre la Corte Interamericana de Derechos Humanos y el Tribunal Europeo de Derechos Humanos en torno al Derecho humano a la identidad cultural..223 Juan Jorge Faundes

Digital ART AND THE BELT AND ROAD INITIATIVE: CHALLENGES AND OPPORTUNITIES 257 Dan Wei e Ângelo Rafael

Policing heritage crime in Latin America. .275 Naomi Oosterman e Donna Yates 
The principles of Cultural Heritage Law based on the Polish Law as an example.292 Małgorzata Joanna Węgrzak e Kamil Zeidler

Heritage Protection in INTERNATIONAL LAw AND NATIONAL LAW: INSIGHTS INTO THE CASE OF VIETNAM

Yen Thi Hong Nguyen e Dung Phuong Nguyen

THE APPROPRIATION OF THE CARIOCA INTANGIBLE CULTURAL HERITAGE BY AN ENTREPRENEURIAL LOGIC

Mário Ferreira de Pragmácio Telles

A Propósito del CARÁcter UNIVERSAL DEL aCCESO A LA CULTURA EN INTERNET: UN ANÁlisis DESDE EL PRISMA INTERNACIONAL Y LA EXPERIENCIA DEL ORDENAMIENTO JURÍDICO CUBANO 344 Janny Carrasco Medina

Direito Humanitário e Arte

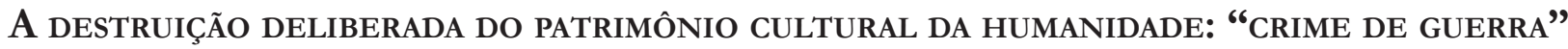
OU "CRIME CONTRA A HUMANIDADE"? Juliette Robichez

Protection OF CULTURAL PROPERTY UNDER INTERNATIONAL HUMANITARIAN LAW: EMERGING TRENDS

Niteesh Kumar Upadhyay e Mahak Rathee

Direito do Mar/Marítimo e Arte.

The underwater Cultural heritage Regime: SOME PROBlems AND POSSible SOlutions. 412 Elina Moustaira

El ROL DEL DERECHO EN LA CONSTRUCCIÓN DEL PATRIMONIO CULTURAL SUBACUÁTICO: APRECiaciones a partirdel estudio del CASo de la Corbeta Inglesa SwifT en Argentina .. 424 Norma Elizabeth Levrand e Nadia Bressan Bernhardt 
INDIGENOUS REFUGEES AND CULTURAL EROSION: POSSIBILITIES AND LIMITS OF INTERNATIONAL REFUGEE AND INDIGENOUS PEOPLES LAW IN THE PROTECTION OF INDIGENOUS CULTURAL EXPRESSIONS RELATED TO TRADITIONAL LAND AND NATIVE LANGUAGE. .440 Rickson Rios Figueira

O RETRATO DE EDMOND BELAMY E A INTERFACE ENTRE ARTE E INTELIGENCIA ARTIFICIAL: POR UMA NOVA DEFINIÇÃo DE AUTORIA E DIREITOS DE PROPRIEDADE INTELECTUAL

Marla Meneses do Amaral Leite Mangiolardo, Patrícia Silva de Almeida e Jonathan Barros Vita

Argumentative aspects of Declaration on the Importance and Value of Universal Museums (2002) 479

Agnieszka Plata

A DestinaÇão dos bens CUlturais EM PROCESSOS PENAIS: A ARTE COMO REPARAÇÃo COLETIVA 488

Inês Virgínia Prado Soares e Otavio Venturini

A Justiça de Pieter Bruegel: direito, violência e a venda nos (nossos) olhos. .501 Rafael Lazzarotto Simioni e Cícero Krupp

Artigos Sobre outros temas

DEVERES INTERNACIONAIS E OBRIGAÇÕES SOCIOAMBIENTAIS PARA EMPRESAS MULTI E TRANSNACIONAIS

Luísa Cortat Simonetti Gonçalves e Adriano Sant'Ana Pedra

Maternidade por substituição: perspectivas da ConferênCia da Haia e suas potenciais INFLUÊNCIAS NO REGRAMENTO BRASILEIRO

Tatiana de A. F. R. Cardoso Squeff e Fernanda Rezende Martins

EL (LARGO) CAMINO DE RECONOCIMIENTO Y EJECUCIÓN DE LAUDOS ARBITRALES DE INVERSIÓN

Thiago Paluma, Ivette Esis e Gabriel Briceño 
A INTERPRETAÇÃo EVOLUTIVA DA CONVENÇÃo AMERICANA SOBRE DiREITOS HUMANOS: UMA REVISÃO DOCUMENTAL DO PERÍODO 1988-2018

Breno Baía Magalhães

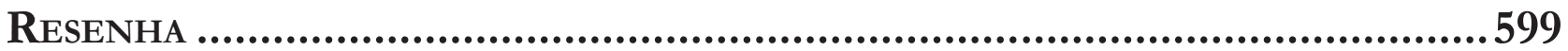

Autonomous Weapons Systems and InTERnATIONAL LAw: A STUDY ON HUMAN-MACHINE INTERACTIONS IN ETHICALLY AND LEGALLY SENSITIVE DOMAINS

Aziz Tuffi Saliba e Lutiana Valadares Fernandes Barbosa 


\title{
Protection of cultural property under international humanitarian law: emerging trends*
}

\author{
Proteção de bens culturais sob o Direito \\ Internacional Humanitário: tendências \\ emergentes
}

Niteesh Kumar Upadhyay**

Mahak Rathee ${ }^{* * *}$

\begin{abstract}
Cultural Properties holds the rich heritage and is a matter of pride for the entire mankind and is considered as property of mankind and does not belong specifically to any religion, group or state. Despite this the cultural property has been attacked and destroyed a lot of times either deliberately or unintentionally during war. The instances of destruction of cultural property has been there in past also and such cases are still increasing. The destruction of cultural property of course creates a sense of divide among people from different communities and nations and not just make chances of compromise between communities and nations impossible but it also lead to long term discrimination and hatred. The legal system related to protection of cultural property is mostly a soft law mechanism in which the implementation body and implementation system is missing and there are many laws which show the importance of cultural property during peacetime and also during war. This paper will discuss in detail about the significance of cultural property, long term effect of destroying of cultural property, Iconoclasm, laws regulating the protection of cultural property during war and peacetime, international criminalization of wrongs against cultural property and suggestions of the authors for protection of cultural property.
\end{abstract}

Keywords: Cultural property. International humanitarian law. Destruction. Protection. Iconoclasm.

* Recebido em 16/08/2020

Aprovado em 28/02/2021

** Research Advisor South Ural State University, Russia and Assistant Professor of Law at Galgotias University India and founder of www.knowledgesteez.com . He is also executive board member of All India Law teachers Congress.

E-mail: niteeshkumar.upadhyay@galgotiasuniversity.edu.in

*** Advocate Supreme Court of India, Global Representative, Roya Institute for Global Justice, Honorary Director (Knowledge Steez EduHub LLP), Founder Consumer Assisto and ADR HOC.

E-mail: ratheemahak@gamil.com

\section{Resumo}

Os bens culturais detêm um rico patrimônio e são motivo de orgulho para toda a humanidade, sendo considerados propriedade da humanidade e não pertencendo especificamente a nenhuma religião, grupo ou estado. Apesar disso, a propriedade cultural tem sido atacada e destruída muitas vezes, deliberada ou involuntariamente, durante a guerra. Os casos de destruição de bens culturais também existiram no passado e esses casos ainda estão aumentando. A destruição de bens culturais, é claro, cria um senso de divisão entre pessoas de diferentes comunidades e nações e não apenas torna as 
chances de compromisso entre comunidades e nações impossíveis, mas também leva à discriminação e ao ódio de longo prazo. O sistema jurídico relacionado à proteção da cultura a propriedade é principalmente um mecanismo de soft law no qual o órgão de implementação e o sistema de implementação estão ausentes e existem muitas leis que mostram a importância da propriedade cultural em tempos de paz e também durante a guerra. Este artigo discutirá em detalhes sobre a importância da propriedade cultural, efeito de longo prazo da destruição de propriedade cultural, iconoclastia, leis que regulam a proteção da propriedade cultural durante a guerra e em tempos de paz, criminalização internacional de injustiças contra propriedade cultural e sugestões dos autores para proteção de propriedade cultural.

Palavras-chave: Bens culturais, Direito internacional humanitário, destruição e proteção de bens culturais, iconoclastia

\section{Introduction}

Through codified International Law, the world has reached a common consensus after World War II that the historic monuments, archaeological sites, artwork and other cultural property is considered as the property of mankind and not of any particular religion, state or any group ${ }^{1}$.

Cultural Property ${ }^{2}$ is the pride of any community and its significance increases as time passes. No geopolitical boundaries can stop people from visiting and admiring cultural property and these properties do not belong to any particular country or group of people but to the whole mankind. Cultural Property is not only of cultural relevance but it is also a mark of identity of groups and communities. Cultural Property also serves as repository of customs, tradition and usages followed

1 HARVARD LAW SCHOOL. Art in time of war: pillage, plunder, repression, reparations and restitution. Available at: http://www.law. harvard.edu/faculty/martin/art_law/war.htm\#: :text=places $\% 20$ of $\% 20$ worship-, Without $\% 20$ prejudice $\% 20$ to $\% 20$ the $\% 20$ provisions $\% 20$ of $\% 20$ the $\% 20$ Hague $\% 20$ Convention $\% 20$ for, the $\% 20$ cultural $\% 20$ or $\% 20$ spiritual\%20heritage Accessed on: 29 Aug. 2020.

2 Cultural property is non-renewable resources that includes but not limited to works of art, old buildings or their ruins, museums, library, scriptures, archives, historic buildings and monuments, archaeological sites and artifacts found on land or underwater, places of worship and other sacred places like churches, mosques, temples, idols, shrines, sanctuaries, mountain, cemeteries etc by a particular group or community and also serve a tool of self-identification for such communities ${ }^{3}$.

Though as discussed above Cultural Property has a lot of significance, even then it is attacked and is damaged intentionally or unintentionally during war and the after effects of the same can be seen in form of long time rivalry even after the war is over between two communities. Modern day warfare involves more destructive technology and hence inflicts more loss to cultural property. Recently we have seen mass destruction of cultural property in the Middle East and North Africa. There have been countless statements from UNESCO , United Nation and many non-governmental organizations and activists condemning targeting of cultural property in recent times but this did not had any effect on the number of targeted attacks on cultural property. The international law related to cultural property is basically regulated by customary international law and the soft law mechanism which has many features pertaining to protection of cultural property at international level is still in its evolving stage. The present legal regime has no deterrence in case if any cultural property is targeted and hence the implementation of the soft law and customary law is very weak ${ }^{4}$.

The reasons for the Intentional attack on cultural property could be various including but not limited to dehumanization of other community, hatred, discrimination, intention to exterminate the community and its cultural property. Sometimes attack on these cultural property is also done during non-international armed conflict in order to gather attention of international community for recognition and financial assistance for example destruction of cultural property which was a colossal image of Buddha at Bamiyan in year 2001 in Afghanistan ${ }^{5}$.

The attacks on cultural property devalue the con-

3 CENTER FOR THE ENVIRONMENTAL MANAGEMENT OF MILITARY LANDS. Types of Cultural Property. Available at: https://www.cemml.colostate.edu/cultural/09476/chp0402iraqenl.html Accessed on: 29 Aug. 2020.

4 GERSTENBLITH, Patty. The destruction of cultural heritage: a crime against property or a crime against people? J. Marshall Rev. Intell. Prop. L., n. 15, 2016. Available at: https://repository.jmls.edu/ cgi $/$ viewcontent. cgi?article $=1382 \&$ context $=$ ripl Accessed on: 29 Aug. 2020.

5 MORGAN, L. The Buddhas of Bamiyan. Cambridge, Massachusetts: Harvard University Press, 2012. Available at: www.jstor.org/ stable/j.ctt2jbt4h, Accessed on: 29 Aug. 2020. 
cept of Cultural pluralism ${ }^{6}$ and multiculturalism ${ }^{7}$ which is very important and essential for modern day civil society.

International Humanitarian Law allows attack on any property including cultural property in certain conditions stating it as military necessity ${ }^{8}$. Military necessity gives a high contracting party some military advantage ${ }^{9}$ for example if any place is used for keeping weapons, aircrafts, armored vehicles or any other material vital for warfare like petroleum processing units, energy production units etc. are considered to be legitimate targets of attack ${ }^{10}$. Also the cultural property is protected by customary international law principles of distinction between civilian objects and military objects as Rule 7 of customary international humanitarian law. The rules state that high contracting parties to armed conflict need to ensure that they can distinguish civilian objects and military objects and all attacks must be directed to military objects only. Cultural property though cannot be true sense be said to be civilian property but surely not as a military object ${ }^{11}$.

Jurists of international law have clearly mentioned that whatever might be the reason for armed conflict or waging war against any state or territory, building

\footnotetext{
Cultural pluralism means when smaller ethnic group within a larger society maintain their unique values, practices, customs and traditions without being inconsistent with the values, practices, customs and traditions of wider society.

Multiculturalism is the concept under which society deals with its cultural diversity both at national and community level. multiculturalism assumes that everyone benefits from cultural diversity and for the best interest of society as whole all these cultural diversities to be harmoniously maintained with each other in the society.

8 HAYASHI, Nobuo. Requirements of military necessity in international humanitarian law and international criminal law. Boston University International Law Journal, n. 28, p. 41-139, 2010. Available at: https://www.bu.edu/law/journals-archive/international/documents/39-140.pdf Accessed on: 29 Aug. 2020.

9 BOOHER, Alice A. The military advantage: the military.com guide to military and veterans benefits. Available at: https://www.bva. va.gov/docs/VLR_VOL2/Copy12--AliceBooher.pdf Accessed on: 29 Aug. 2020.

10 GENERAL COUNSEL OF THE DEPARTAMENT OF DEFENSE. Department of Defense Law of War Manual. 2015. Available at: https://dod.defense.gov/Portals/1/Documents/pubs/DoD $\% 20$ Law $\% 20$ of $\% 20$ War $\% 20$ Manual $\% 20$-\%20June $\% 202015 \% 20$ Updated $\% 20$ Dec $\% 202016$. pdf?ver $=2016-12-13-172036-190$ Accessed on: 29 Aug. 2020.

11 HENCKAERTS, Jean-Marie; DOSWALD-BECK, Louise. Customary International Humanitarian Law. New York: Cambridge University Press, 2005. Available at: https://www.icrc.org/en/doc/assets/ files/other/customary-international-humanitarian-law-i-icrc-eng. pdf Accessed on: 29 Aug. 2020.
}

and works of cultural importance must be spared .Since destroying these cultural properties provides no gain to any high contracting parties, these properties in no way contribute to strengthen the enemy armies and by destroying them the whole world and coming generations are being deprived of some masterpiece which cannot be reconstructed and hence it is a crime against the mankind ${ }^{12}$.

Three significant limitations have been imposed for the protection which have been granted to cultural property. The first obligation is to mark such cultural property with distinctive emblem like blue shield or any other emblem but this needs to be communicated to enemy in advance ${ }^{13}$. The second limitation is the obligation on all high contracting parties to avoid causing damage to any cultural property but it has been limited by a phrase "as far as possible" and hence in case of exigencies can be attacked ${ }^{14}$. The third and the last limitation is to avoid using cultural property for the military purposes and also all possible caution to be taken to keep military and military objects far from cultural property. Even after all the above three limitations because of nature of modern warfare and arms used the chances of destruction of these cultural properties is high especially in cases of non-international armed conflict, ethnic cleansing ${ }^{15}$ and terrorist attacks ${ }^{16}$.

\section{Long term effects of destroying of cultural property}

Armed conflict between different nations and communities have not only created human loss but have

12 MILLIGAN, A. Targeting cultural property: the role of international law. Available at: https://jpia.princeton.edu/sites/jpia/ files/2008-5.pdf Accessed on: 29 Aug. 2020.

13 BHAT, P. Protection of cultural property under international humanitarian law: some emerging trends. 2001. Available at http://www.commonlii.org/in/journals/ISILYBIHRL/2001/4.html Accessed on: 29 Aug. 2020.

14 MARKING of cultural property with emblems of the 1954 Hague Convention. Available at: https://www.cemml.colostate. edu/cultural/09476/chp04-10egyptenl.html Accessed on: 29 Aug. 2020.

15 PETROVIC, Drazen. Ethnic cleansing: an attempt at methodology. 1994. Available at: http://www.ejil.org/pdfs/5/1/1247.pdf Accessed on: 29 Aug. 2020.

16 FLIPPO, R. Attacks against cultural property as a weapon of war: an exploratory case study. Available at: https://www.ibei.org/ibei_studentpaper34_105354.pdf Accessed on: 29 Aug. 2020. 
also created a long term divide between two nations and communities but we have seen that with passage of time nations and communities have learned to stay and live together ${ }^{17}$ For example the Vietnamese war between armies of South and North Vietnam including allies from USA and USSR and this example clearly illustrate that after the end of a war the situation is fine and people are living together in harmony. Also in the case of Sudan and South Sudan we have seen in the recent past that relation and friendship between the two countries are getting stronger. International Humanitarian law one of the most important principle is that friendship should be possible after that last bullet is fired whereas destruction of cultural property creates a long time scar in the hearts and minds of people which can be a reason for war and conflict ${ }^{18}$. Armed conflict if leads to destroying of cultural property can generate anger in subsequent generations and can prove to be a breeding ground or motive for retaliation and armed conflict ${ }^{19}$.

The destroying of cultural property creates a sense of divide among people from different communities and nations and not just make chances of compromise between communities and nations impossible but also lead to long term discrimination and hatred ${ }^{20}$. The fuel to fire can be added by mass media and information communication technology which will spread the news of destruction of cultural property like fire and can also increase tension among communities and nations who are not in direct war or hostiles with each other ${ }^{21}$. Let's

\footnotetext{
LASSON, Kenneth. Incitement in the Mosques: testing the limits of free speech and religious liberty. Whittier L. Rev., n. 27, 2005. Available at: https://scholarworks.law.ubalt.edu/cgi/viewcontent. cgi?article $=1384 \&$ context=all_fac Accessed on: 29 Aug. 2020 .

18 BHAT, P. Protection of cultural property under international humanitarian law: some emerging trends. 2001. Available at http://www.commonlii.org/in/journals/ISILYBIHRL/2001/4.html Accessed on: 29 Aug. 2020.

19 GERSTENBLITH, Patty. The destruction of cultural heritage: a crime against property or a crime against people? J. Marshall Rev. Intell. Prop. L., n. 15, 2016. Available at: https://repository.jmls.edu/ cgi $/$ viewcontent.cgi?article $=1382 \&$ context $=$ ripl Accessed on: 29 Aug. 2020.

20 RICHARD, Lieutenant Colonel Theodore T. Nuclear weapons targeting: the evolution of law and U.S. Policy, Military Law Review, v. 224, n. 4, 2016. Available at: https://www.loc.gov/rr/frd/Military_Law/Military_Law_Review/pdf-files/224-issue4-2016.pdf Accessed on: 29 Aug. 2020.

21 MYEROWITZ, Elissa S. Protecting cultural property during a time of war: why Russia should return nazi-looted art. Fordham International Law Journal, n. 20, 1996. Available at: https://ir.lawnet. fordham.edu/cgi/viewcontent.cgi?referer=https://www.google.co $\mathrm{m} /$ \&httpsredir $=1 \&$ article $=1808 \&$ context $=\mathrm{ilj}$ Accessed on: 29 Aug. 2020 .
}

assume a situation in which religious place of one community is destroyed by another community in one state but this will not end here people who are in other country will also feel unsafe and kind of hatred will increase in their mind and hearts for other community ${ }^{22}$.

\section{Instances of damage to cultural property during international, non- international armed conflict and terrorists attacks and cause of such acts}

The destruction of cultural property has significantly increased in the recent past and is still increasing at a very high rate. The recent conflict in Syria ${ }^{23}, \mathrm{Iraq}^{24}$ and $\mathrm{Mali}^{25}$ has reflected the inefficacy of our international legal regime. There are many ways wherein cultural property in all the three above mentioned nations got damaged such as some properties got damaged because of intentional bombardment, while some got damaged because of accidental collateral damages during armed conflict because of indiscriminate firing of guns and mortars, some were targeted to clear path for war, some cultural properties were used for military purpose and hence became legitimate object of attack, some cultural properties suffered damage because of looting and illicit trade of cultural property ${ }^{26}$. Apart from this damage to these cultural properties is also done by internally dis-

22 CULTURAL Heritage. Available at: https://www.peacepalacelibrary.nl/research-guides/special-topics/cultural-heritage/ Accessed on: 29 Aug. 2020.

23 CUNLIFFE, Emma et al. The destruction of cultural property in the Syrian Conflict: legal implications and obligations. International Journal of Cultural Property, n. 23, p. 1-31, 2016. Available at: https:// www.cambridge.org/core/journals/international-journal-of-cultural-property/article/destruction-of-cultural-property-in-the-syrianconflict-legal-implications-and-obligations/5B81E9C84C7F9B24FA0C4F1E9FA50CAF/core-reader Accessed on: 29 Aug. 2020.

THURLOW, Matthew D. Protecting cultural property in Iraq: how american military policy comports with international law. Yale Hum. RTS \& DEV. L. J., n. 8, 2005. Available at: https://digitalcommons.law.yale.edu/cgi/viewcontent. cgi? article $=1050 \&$ context $=$ yhrdlj Accessed on: 29 Aug. 2020 .

25 MALI, accountability for the destruction of cultural heritage. Available at: https://casebook.icrc.org/case-study/mali-accountability-destruction-cultural-heritage Accessed on: 29 Aug. 2020.

26 UNESCO. The fight against the illicit trafficking of cultural objects the 1970 convention: past and future. Available at: http://www.unesco. org/new/fileadmin/MULTIMEDIA/HQ/CLT/pdf/2013_INFOKIT_1970_EN.pdf Accessed on: 29 Aug. 2020. 
placed people who have been displaced because of war. These people took shelter in many of such properties which are of cultural relevance and since these properties have been used a human habitat,wear and tear has become quite evident ${ }^{27}$. Gulf war $^{28}$ has seen this massive destruction of cultural property by rebel groups and also in case of former Yugoslavia involved destruction of Sarajevo's numerous cultural property including Mosques, churches, museums and library which were made way back in $14^{\text {th }}$ or $15^{\text {th }}$ century and have a lot cultural and social relevance ${ }^{29}$. The most historic town of Europe has also faced destruction of more than $60 \%$ of cultural property which can be dated back to 15 th and 16 th century ${ }^{30}$.

\section{Iconoclasm and destruction of cultural heritage}

Iconoclasm is defined as destruction of icons, images and monuments for religious and political motivation $^{31}$. Iconoclasm has become very prevalent and many times it has been used as a military tactic in order to demoralize people of one particular religion or ethnicity. The practice or tactic of Iconoclasm is a very old concept and can be dated back to hundreds of years and one such mention can be found in Hebrew bible or old testament which instructs the Israelites to destroy all graveyard stones, images, and high places of the Canaanite population ${ }^{32}$. The first act of Iconoclasm in

${ }_{27}$ ICCROM. Protecting cultural heritage in times of conflict. Available at: https://www.iccrom.org/sites/default/files/ICCROM_18_ProtectingHeritageConflict_en.pdf Accessed on: 29 Aug. 2020.

28 FORSYTH, Marion. Casualties of war: the destruction of Iraq's cultural heritage as a result of U.S. action during and after the 1991 Gulf War. DePaul J. Art, Tech. \& Intell. Prop. L., v. 14, 2004. Available at: https://via.library.depaul.edu/cgi/viewcontent. cgi? referer=https: / www.google.com/ \&httpsredir=1\&article $=120$ 2\&context=jatip Accessed on: 29 Aug. 2020.

${ }^{29}$ KOSSIAKOFF, Megan. The art of war: the protection of cultural property during the "Siege" of Sarajevo(1992-95). DePaul Journal of Art, Technology and Intellectual Property Law, v. 14, 2004. Available at: https://via.library.depaul.edu/cgi/viewcontent. cgi?article $=1203 \&$ context=jatip Accessed on: 29 Aug. 2020 .

30 PAVLOVIC, Srda. The siege of Dubrovnik and the consequences of the War for peace'. 2009. Available at: https://pescanik.net/the-siege-ofdubrovnik-and-the-consequences-of-the-war-for-peace/ Accessed on: 29 Aug. 2020.

31 ELSNER, Jas. Iconoclasm as discourse: from antiquity to Byzantium. The Art Bulletin, n. 94, p. 368-394, 2012. Available at: https://www.jstor.org/stable/23268277 Accessed on: 29 Aug. 2020. 32 STEWART, D. Why did God order the destruction of the Canaanites?
Islamic history began in the year 630 when many statues of Arabian deities kept at Kabba in Mecca were vandalized $^{33}$. The Hagia Sophia is a fine example as to how a church can be converted to mosque and then to a museum and then again to a mosque ${ }^{34}$. Persian King around year 484-430 BC plundered Greek and Egyptian religious and cultural property and centers ${ }^{35}$. History has witnessed many mosques and churches being destroyed for instance in Serbian War, according to one of the report around 400 mosques and approximately 200 churches were vandalized ${ }^{36}$.

The attacks on cultural property devalue the concept of Cultural pluralism ${ }^{37}$ and multiculturalism ${ }^{38}$ which is a very important essential of modern day civil society.

International Humanitarian Law allows attack on any property including cultural property in certain conditions calling it as military necessity ${ }^{39}$. Military necessity is something which gives a high contracting party some military advantage ${ }^{40}$ for example if any place is

Available at: https://www.blueletterbible.org/faq/don_stewart/ don_stewart_1382.cfm Accessed on: 29 Aug. 2020.

33 MACAULEY-LEWIS, Elizabeth. The history of art and architeture in the islamic world. Available at: https://brewminate.com/thehistory-of-art-and-architecture-in-the-islamic-world/ Accessed on: 29 Aug. 2020.

34 WEGNER, Emma. "Hagia Sophia, 532-37." 2004. Available at: http://www.metmuseum.org/toah/hd/haso/hd_haso.htm Accessed on: 29 Aug. 2020.

35 HERODOTUS. Herodotus: on the customs of the persians. 2012. Available at: https://www.ancient.eu/article/149/herodotuson-the-customs-of-the-persians/ Accessed on: 29 Aug. 2020.

36 MOSE, Gregory M. The destruction of churches and mosques in Bosnia- Herzegovina: seeking a rights-based approach to the protection of religious cultural property. Buffalo Journal of International Law, n. 3, 1996. Available at: https://digitalcommons.law.buffalo. $\mathrm{edu} / \mathrm{cgi} / \mathrm{viewcontent}$.cgi?article $=1028 \&$ context $=$ bjil Accessed on: 29 Aug. 2020.

37 Cultural pluralism means when smaller ethnic group within a larger society maintain their unique values, practices, customs and traditions without being inconsistent with the values, practices, customs and traditions of wider society.

38 Multiculturalism is the concept under which society deals with its cultural diversity both at national and community level. multiculturalism assumes that everyone benefits from cultural diversity and for the bestinterest of society as whole all these cultural diversities to be harmoniously maintained with each other in the society.

39 HAYASHI, Nobuo. Requirements of military necessity in international humanitarian law and international criminal law. Boston University International Law Journal, n. 28, p. 41-139, 2010. Available at: https://www.bu.edu/law/journals-archive/international/documents/39-140.pdf Accessed on: 29 Aug. 2020.

40 BOOHER, Alice A. The military advantage: the military.com guide to military and veterans benefits. Available at: https://www.bva. va.gov/docs/VLR_VOL2/Copy12--AliceBooher.pdf Accessed on: 29 Aug. 2020. 
used for keeping weapons, aircrafts, armored vehicles or any other material vital for warfare like petroleum processing units, energy production units etc. are considered to be legitimate targets of attack $^{41}$. Also the cultural property is protected by customary international law principle of distinction between civilian objects and military objects as Rule 7 of customary international humanitarian law states that high contracting parties to armed conflict must at all times distinguish between civilian objects and military objects and all attacks must be directed to military objects only. Cultural property though cannot be in true sense be said to be civilian property but surely cannot be treated as a military object ${ }^{42}$.

One of the most notorious examples of Iconoclasm in India was seen when Somnath temple in Gujarat was attacked and destroyed by Mahumud Ghazni. This attack witnessed breaking of jyotirlinga despite pleas by hindu followers not to break it ${ }^{43}$. He looted the temple and took all the money with him as a bounty. Not only this the sentiments of the Hindus were impacted by breaking jyotirlinga and throwing its pieces on the road so people can walk over it. This is not just the only instance of Iconoclasm in India, another such case we can see when Aurangzeb destroyed the temples of Varanasi and Mathura ${ }^{44}$. Not just India but cultural property in many other countries faced destruction and one such example for Asia we can take of destroying of Buddhist temples by General Bai Chongxi and his troops during

41 GENERAL COUNSEL OF THE DEPARTAMENT OF DEFENSE. Department of Defense Law of War Manual.2015. Available at: https://dod.defense.gov/Portals/1/Documents/pubs/DoD $\% 20$ Law $\% 20$ of $\% 20$ War $\% 20$ Manual $\% 20-\% 20 J u n e \% 202015 \% 20$ Updated $\% 20 D e c \% 202016 . p d f$ ?ver $=2016-12-13-172036-190$ Accessed on: 29 Aug. 2020.

${ }^{42}$ HENCKAERTS, Jean-Marie; DOSWALD-BECK, Louise. Customary International Humanitarian Law. New York: Cambridge University Press, 2005. Available at: https://www.icrc.org/en/doc/ assets / files/other/customary-international-humanitarian-law-iicrc-eng.pdf Accessed on: 29 Aug. 2020.

43 SAAVEDRA, Beatriz Wrtinez. Shaping the 'Community': Hindu Nationalist Imagination in Gujarat, 1880-1950. Available at: http:/ / wrap.warwick.ac.uk/57285/7/WRAP_THESIS_Martinez-Saavedra_2013.pdf Accessed on: 29 Aug. 2020.

44 CHETTRY, Aniket Tathagat. Unravelling the myth exploring state and religin under aurangzeb. Glob J Arch \& Antbropol, n. 6, 2018. Available at: https://juniperpublishers.com/gjaa/GJAA. MS.ID.555686.php Accessed on: 29 Aug. 2020. See also PARVEN, Alam. Temple Destruction and the Great Mughals religious policy in North India: a case study of Banaras Region. Analisa Journal of Social Science and Religion, p. 1526-1707. Available at: https://pdfs.semanticscholar.org/3210/fdc936fa3a055c9005aa43de48448edef18a.pdf Accessed on: 29 Aug. 2020. the year $1926^{45}$. In Tibet also we have seen extensive destruction of religious cultural property after it was invaded and occupied by People's Republic of China ${ }^{46}$.

\subsection{Political Iconoclasm}

Change in regime and revolutions against tyranny whether uprising on local population, insurgents ${ }^{47}$, belligerents ${ }^{48}$, foreign invasion ${ }^{49}$ mostly see destruction of statues and cultural property which was important for the former regime or government. Belligerents have looted a lot of cultural property in former Yugoslavia . The 1954 Hague convention on protection of cultural property and its two protocols obligate belligerents to avoid intentional targeting of cultural property but in past we have seen many violations of theis principle lead down in Hague convention ${ }^{50}$.

The past has witnessed many Emperors who erect statues of themselves or their family members which subsequently are destroyed as soon as they are overthrown by the new king or ruler. Roman King Domitian who was king for 81 to $96 \mathrm{AD}$ was assassinated and after his assignation the first thing that happened

45 SCHLUESSEL, Eric Tanner. The muslim emperor of China: everyday politics in colonial Xinjiang, 1877-1933. 2016. Thesis (Doctor of Philosophy) - Harvard University, Cambridge, 2016. Available at: https://dash.harvard.edu/bitstream/handle/1/33493602/ SCHLUESSEL-DISSERTATION-2016.pdf Accessed on: 29 Aug. 2020.

46 SAUTMAN, B. Tibet and the (Mis-) representation of cultural genocide. Available at: https://link.springer.com/content/ pdf/10.1057\%2F9780230601192_6.pdf Accessed on: 29 Aug. 2020. See also SANDHAR, J. Cultural genocide in Tibet: the failure of article 8 of the United Nations Declaration on the Rights of Indigenous Peoples in protecting the cultural rights of Tibetans. Santander Art and Culture Law Review, v. 2, n. 1, 2015. Available at: https:// www.ejournals.eu/SAACLR/2015/2(2015)/art/6788/ Accessed on: 29 Aug. 2020.

47 RASHID, S. et al. Protection of cultural property in the light of international Humanitarian Law. Journal of Critical Reviews, v. 7, n. 6, 2020. Available at: http://www.jcreview.com/fulltext/197-1588576264.pdf Accessed on: 29 Aug. 2020.

48 POSNER, Eric A. The international protection of cultural property: some skeptical observations. Chicago Journal of International Law, n. 8, 2007. Available on https://core.ac.uk/download/ pdf/190354673.pdf Accessed on: 29 Aug. 2020.

49 UNESCO. Protection of cultural property. Available at: http:// www.unesco.org/new/fileadmin/MULTIMEDIA/HQ/CLT/pdf/ MilitaryManuel-En.pdf Accessed on: 29 Aug. 2020.

50 KASTENBERG, Joshua E. The legal regime for protecting cultural property during armed conflict. Air Force Law Review, n. 42, 1997. Available at: https://digitalrepository.unm.edu/cgi/viewcontent.cgi?article $=1423 \&$ context $=$ law_facultyscholarship Accessed on: 29 Aug. 2020. 
was destruction of all statue of Domitian ${ }^{51}$. Similar situation was witnessed in case of emperor Commodus who was king of Rome during 180-192 AD and after his assassination also the statue of him and his father were destroyed ${ }^{52}$.

After French revolution we have seen a paradoxical nature of Republican government and French citizenry as on one hand they want to destroy all monuments , religious places, buildings belonging to old regime and on other hand they want to preserve their rich cultural heritage for which they constructed many museums ${ }^{53}$. There is not an iota of doubt many culturally significant properties were destroyed because of half hearted attempts of republican government ${ }^{54}$.

\subsection{Reasons behind Iconoclasm}

There are various reasons for Iconoclasm and the most important is hatred against anyone based on religion, nation, caste, social group or political opinion. Hatred creates enmity in mind of political leaders, armies and citizenry to such an extent that they can do anything to overthrow it and also they don't want that any trace of it could be found in future which could remind them of such old regimes, people, and religion. Pro-Nazi Vichy Government of France destroyed the Clothilde Roch's statue of 16th century because of the reason that vichy authorities disliked the statue and this was done as part of celebration of freedom of consciences $^{55}$.

One of the other main reason for Iconoclasm is to discourage any group of people belonging to any nationality, religion or part of social group to an extent that

51 RASHID, S. et al. Protection of cultural property in the light of international Humanitarian Law. Journal of Critical Reviews, v. 7, n. 6, 2020. Available at: http://www.jcreview.com/fulltext/197-1588576264.pdf Accessed on: 29 Aug. 2020.

52 MEZEY, Naomi. The paradoxes of cultural property. Colum. L. Rev., n. 107, p. 2004-2046, 2007. Available at: https:/ / scholarship.law.georgetown.edu/cgi/viewcontent. cgi?article $=1902 \&$ context $=$ facpub Accessed on: 29 Aug. 2020.

53 MCDONALD, David (ed.). Culture under fire: Armed Non-State actors and Cultural Heritage in wartime. 2018. Available at: https:/ / genevacall.org/wp-content/uploads/2017/10/Cultural_Heritage_ Study_Final.pdf Accessed on: 29 Aug. 2020.

${ }^{54}$ MOUSTAKAS, J. Group rights in cultural property: justifying strict inalienability. Cornell Law Review, n. 74, 1989. Available at: https:// core.ac.uk/download/pdf/216738239.pdf Accessed on: 29 Aug. 2020.

55 ICONOCLASTS Battle. Available at: https://scannerfasr942. weebly.com/iconoclasts-battle-1.html Accessed on: 29 Aug. 2020. they will like to lose their identity and will not like to disclose any who they are and what they believe in and what they practice ${ }^{56}$. Many a times Iconoclasm is done to discourage traditional and religious practices performed at religious and cultural sites ${ }^{57}$. Curbing growth of any religion and followers of it is one of the main reasons for Iconoclasm. One such example is of Soviet Union when they destroyed religious cultural property including Russian Orthodox Churches and Jewish Cemeteries with a motive to discourage followers of such religious instructions ${ }^{58}$.

Iconoclasm sometimes is done to remove the name of any religion or community from history. Mostly when one state is taken over by another or one regime changes to another the ruling regime try to destroy cultural and religious places so that subordination of people of such community whose religious and cultural property is destroyed become easy. Iconoclasm hurts their belief system and they start following all commands of the ruling regime with much resistance.

Iconoclasm also happens sometimes because one ruler is overthrown and the regime that has overthrown him wants to show to the world the end of the regime of the old ruler. For example Firdos Square Destructions of Saddam Hussein ${ }^{59}$ statue can be seen as symbolic end of Bagdad war between Iraq and United States of America ${ }^{60}$. No doubt the main reason of Iconoclasm is always hatred and intention of deleting history about old regime, religion and communities ${ }^{61}$.

56 SHERWIN, R. Law, metaphysics, and the new iconoclasm. Law Text Culture, n. 11, p. 70-105, 2007. Available at: https://ro.uow.edu. $\mathrm{au} / \mathrm{cgi} /$ viewcontent.cgi?article $=1040 \&$ context=ltc Accessed on: 29 Aug. 2020.

57 RICHARD, Lieutenant Colonel Theodore T. Nuclear weapons targeting: the evolution of law and U.S. Policy, Military Law Review, v. 224, n. 4, 2016. Available at: https://www.loc.gov/rr/frd/Military_Law/Military_Law_Review/pdf-files/224-issue4-2016.pdf Accessed on: 29 Aug. 2020.

58 WANGKEO, K. Monumental challenges: the lawfulness of destroying cultural heritage during peacetime. The Yale Journal of International Law, v. 28, p. 183-274, 2003. Available at: https:/ digitalcommons.law.yale.edu $/$ cgi $/$ viewcontent.cgi? article $=1206 \&$ context $=$ yjil Accessed on: 29 Aug. 2020.

59 DALE, Catherine. Operation Iraqi freedom: strategies, approaches, results and issues of congress. 2009. Available at: https://fas.org/ sgp/crs/natsec/RL34387.pdf Accessed on: 29 Aug. 2020.

${ }_{60}$ The Navy seal of USA pulled down the statue of Saddam Hussein from Firdos Square at Bagdad

61 FREEDBERG, D. Art and Iconoclasm, 1525-1580, the case of the Northern Netherlands. Available at: http://www.columbia.edu/cu/arthistory/faculty/Freedberg/Art-and-Iconoclasm.pdf Accessed on: 29 Aug. 2020. 


\section{Religious texts e the significance of cultural property}

We can trace the ancient law of war in the old testament. ${ }^{62} \mathrm{It}$ has been mentioned in the war code of DEUTERONOMY that when you attack an enemy nation which is far off, put all the males of the enemy country to sword if they fight with you and if they surrender, make them slave. It also mentions that you can take women, little ones, cattles and any other valuable thing as a bounty of war. The war code expressly orders the army to kill and destroy the Hittites and the Amorites, the Canaanites and the Perizittes, the Hivites and the Jebusites because they should not teach you about their God .This war code reflects the early views of civilization towards destruction of the enemy center for religious beliefs. The common objective of such destruction of religious belief is that the conquered people will easily start following the conquering state and lose its identity ${ }^{63}$.

Many a times religious places are used for inciting violence and war including destruction of cultural and religious property of other religion but still these places cannot be targeted during war ${ }^{64}$. The problem here in regarding the protection of these cultural properties increases many fold when the conflict is non-international armed conflict or act of terrorists because in such cases, they are not governed by most of the international law for example the great Mosque of Al-Nuri and its iconic leaning minaret was destroyed by ISIS in northern $\operatorname{Iraq}^{65}$.

\footnotetext{
${ }^{62}$ OLD Testament. Available at: https://www.catholic.org/bible/ old_testament.php Accessed on: 29 Aug. 2020.

63 KASTENBERG, Joshua E. The legal regime for protecting cultural property during armed conflict. Air Force Law Review, n. 42, 1997. Available at: https://digitalrepository.unm.edu/cgi/viewcontent.cgi? article $=1423 \&$ context $=$ law_facultyscholarship Accessed on: 29 Aug. 2020.

${ }^{64} \mathrm{LASSON}$, Kenneth. Incitement in the Mosques: testing the limits of free speech and religious liberty. Whittier L. Rev., n. 27, 2005. Available at: https://scholarworks.law.ubalt.edu/cgi/viewcontent. cgi?article=1384\&context=all_fac Accessed on: 29 Aug. 2020.

${ }_{65}$ ISAKHAN, Benjamin; ZARANDONA, Jose Antonio Gonzalez. Destroying Mosul's Great Mosque: Islamic State's symbolic war to the end. 2014. Available at: https://theconversation.com/destroying-mosuls-great-mosque-islamic-states-symbolic-war-to-theend-80002 Accessed on: 29 Aug. 2020.
}

\section{Laws regulating protection of cultural property during war and peacetime}

The legal system related to protection of cultural property is mostly a soft law mechanism in which the implementation body and implementation system is missing. There are many laws which show the importance of cultural property during peacetime and also during war. People's republic of China destroyed many places of cultural importance in Tibet ${ }^{66}$ which clearly violates Article 8 of United Nation Declaration on the Rights of Indigenous People but as this law is soft law and have no body and system which can implement or punish perpetrator of such damage to cultural property $^{67}$. The attack of China on Tibet's cultural property is also seen as cultural genocide by many jurists and states but still it continued for very long time ${ }^{68}$. The great Polish jurist and lawyer Rafael Lemkin in 1933 stated that destruction of cultural property is one of the eight dimensions of genocide, political, social, cultural, economic, biological, physical, religious, and moral and each of these target a different aspect of an ethic group. Rafael Lemkin also suggested that barbarism and vandalism should be added to the preexisting list of acts against law of nations. He stated that an act targeting cultural property can be seen as systematic and organized destruction of any particular community ${ }^{69}$.

Customary international law regime also protects cultural property and under Rule 38 Published by International Committee of Red Cross each high contracting party of the conflict should take special care during hostilities to avoid damage to cultural property unless

66 COMMISSION INTERNATIONALE DE JURISTES. The question of Tibet and the rule of law. 1959. Available at: http://www. icj.org/wp-content/uploads/1959/01/Tibet-rule-of-law-report1959-eng.pdf Accessed on: 29 Aug. 2020.

67 UNITED NATIONS. United Nations Declaration on the rights of Indigenous Peoples. Available at: https://www.un.org/development/ desa/indigenouspeoples/wp-content/uploads/sites/19/2018/11/ UNDRIP_E_web.pdf Accessed on: 29 Aug. 2020.

68 SANDHAR, J. Cultural genocide in Tibet: the failure of article 8 of the United Nations Declaration on the Rights of Indigenous Peoples in protecting the cultural rights of Tibetans. Santander Art and Culture Law Review, v. 2, n. 1, 2015. Available at: https://www. ejournals.eu/SAACLR/2015/2(2015)/art/6788/ Accessed on: 29 Aug. 2020.

69 LEMKIN, R. Acts constituting a general (transnational) danger considered as offences against the law of nations. 1993. Available at: http:/ / www. preventgenocide.org/lemkin/madrid1933-english.htm Accessed on: 29 Aug. 2020. 
they are used for military purpose and are legitimate military objective ${ }^{70}$.

The general order 100 also popularly known as Lieber code was instruction signed by Abraham Lincoln during American civil war and dictates how soldiers should conduct at all times during $\mathrm{War}^{71}$. The Lieber code under Article 35 and Article 36 is attempting to protect cultural property and lays down that cultural property including Classical works of art, libraries, scientific collections, or precious instruments, as well as hospital should never be a point of target and also should be returned to country to whom it belongs if stolen. Brussels declaration under its Article 17 reiterated the above principle mentioned under article 35 and 36 of Lieber code and also imposes a duty on country to whom such cultural property belongs to use emble$\mathrm{ms}$ to create distinctiveness and also that said emblem to be communicated to enemy beforehand ${ }^{72}$.

The Oxford Manual of 1880 went a step ahead by having provisions penalizing offenders who destroy cultural property ${ }^{73}$. Liability to pay compensation has been imposed by The Hague Convention of 1907 upon the belligerent party responsible for violation. Oxford Manual 1880 under Article 34 provides provisions for protection of cultural property and forbids the willful destruction of such property expect in case of military necessity ${ }^{74}$. Under Rule 40 theft, pillage ormisappropriation or vandalism of cultural property is also prohibited $^{75}$.

\footnotetext{
70 INTERNATIONAL COMMITTEE OF THE RED CROSS. Rule 38, ICRC on customary IHL. Available at: https://ihl-databases. icrc.org/customary-ihl/eng/docs/v1_rul_rule38 Accessed on: 29 Aug. 2020.

${ }^{71}$ AVALON PROJECT. The Lieber Code. 1863. Available at: https://avalon.law.yale.edu/19th_century/lieber.asp\#sec2 Accessed on: 29 Aug. 2020.

${ }_{72}$ U.S. COMMITTEE OF THE BLUE SHIELD. Laws and Treaties protecting cultural property: 1874 Brussels Declaration. Available at: https://uscbs.org/1880-oxford-manual.html Accessed on: 29 Aug. 2020.

73 INTERNATIONAL COMMITTEE OF THE RED CROSS. Rule 40, ICRC on customary IHL. Available at: https://ihl-databases. icrc.org/customary-ihl/eng/docs/v2_rul_rule40 Accessed on: 29 Aug. 2020.

74 U.S. COMMITTEE OF THE BLUE SHIELD. Laws and Treaties protecting cultural property: 1874 Brussels Declaration. Available at: https://uscbs.org/1880-oxford-manual.html Accessed on: 29 Aug. 2020.

75 INTERNATIONAL COMMITTEE OF THE RED CROSS. Rule 40, ICRC on customary IHL. Available at: https://ihl-databases. icrc.org/customary-ihl/eng/docs/v2_rul_rule40 Accessed on: 29 Aug. 2020.
}

Hague Air Rules 1923 which is codified by USA, Japanese Imperial Foreign Office and some other European Nations under its Article 25discusses the rules related to non-targeting of cultural propertybut Hague Air Rules 1923 were never adopted by any nation because they were very strict and were not acceptable to any nation ${ }^{76}$. These rules never come in force and remain insignificant in protecting cultural property. International pacts like Roerich Pact $1935^{77}$ also have provision cultural property from being targeted by anyone during war or peace also an international duty to respect and protect cultural property was also lead down by under Inter-Allied Declaration $1943^{78}$.

The treaty of peace with Germany also known as the Treaty of Versailles under its Article 245 also forced Germany to return all stolen cultural property to France. Germany was asked to return all cultural property that they had stolen during the 1870-1871 war and also during the last war. Under Article 246 Germany was also asked to return within the timespan of six months the original Koran of Claph Othman which was presented to German William II by Turkish authorities who removed the original koran from Medina. The treaty of Versailles was signed after defeat of Germany in world war $\mathrm{I}^{79}$.

Additional Protocol to Geneva Conventions 1949 and also Protocol I of 1977 for protection of Victims of International Armed Conflicts under its Article 53 states that cultural object and Places of worship should not be target of attack and also prohibits use of such cultural property as support system during war and also to make such cultural property the object of reprisal. Article 16 of additional protocol of Geneva convention 1949 also prohibits use of any cultural property for

${ }_{76}$ THE HAGUE Rules of Air Warfare. 1922. Available at: https://wwi.lib.byu.edu/index.php/The_Hague_Rules_of_Air_Warfare Accessed on: 29 Aug. 2020.

INTERNATIONAL COMMITTEE OF THE RED CROSS. Treaty on the Protection of Artistic and Scientific Institutions and Historic Monuments, (April 15, 1935). Available at: https://ihl-databases.icrc. org/ihl/INTRO/325?OpenDocument Accessed on: 29 Aug. 2020. 78 ZHANG YUE. Customary International Law and the Rule against taking cultural property as spoils of war. Chinese Journal of International Law, v. 17, p. 943-989, 2018. Available at: https:/ /academic.oup.com/chinesejil/article-pdf/17/4/943/27275819/jmy030. pdf Accessed on: 29 Aug. 2020.

79 GERMANY. Treaty of Peace with Germany (Treaty of Versailles). Available at: https://www.loc.gov/law/help/us-treaties/bevans/must000002-0043.pdf Accessed on: 29 Aug. 2020. 
support of military effort ${ }^{80}$. Hague Convention 1954 under its preamble also recites the importance of cultural property by saying that cultural property belongs to mankind and it's important for culture of the world also emphasizing on importance of preserving cultural property and states that this heritage shall receive international protection.

Convention for the Protection of Cultural Property in the Event of Armed Conflict with Regulations for the Execution of the Convention 1954 under Article 9 provides for immunity of cultural property from any kind of attack during war and creates an internally recognized emblem for protection of cultural property. The use of emblem is inductive that the marked property is cultural property and hence immune from any type of military attacks ${ }^{81}$. Article 11 of the Convention includes provision for withdrawal of immunity for such cultural property protected under Article 9 when such property is used for military purposes. Article 12 and Article 13 of convention provides provisions for protection of cultural property during transport but carrying distinctive emblem and notifying the opposing high contracting party ${ }^{82}$. Article 14 of the convention prohibits seizure of any cultural property as bounty of war $^{83}$ and Article 16 provides blue shield for protection of cultural property ${ }^{84}$.

\footnotetext{
80 HARVARD LAW SCHOOL. Art in time of war: pillage, plunder, repression, reparations and restitution. Available at: http://www.law. harvard.edu/faculty/martin/art_law/war.htm\#: :text=places $\% 20$ of $\% 20$ worship-, Without $\% 20$ prejudice $\% 20$ to $\% 20$ the $\% 20$ provisions $\% 20$ of $\% 20$ the $\% 20$ Hague $\% 20$ Convention $\% 20$ for, the $\% 20$ cultural $\% 20$ or $\% 20$ spiritual $\% 20$ heritage Accessed on: 29 Aug. 2020.

81 UNESCO. Convention for the protection of cultural property in the event of armed conflict with regulations for the execution of the convention 1954. Available at: http://portal.unesco.org/en/ev.php-URL_

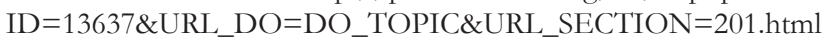
Accessed on: 29 Aug. 2020.

82 BHAT, P. Protection of cultural property under international bumanitarian law: some emerging trends. 2001. Available at http://www.commonlii.org/in/journals/ISILYBIHRL/2001/4.html Accessed on: 29 Aug. 2020.

83 UNITED NATIONS EDUCATIONAL, SCIENTIFIC AND CULTURAL ORGANIZATION. Fighting the Illicit Trafficking of cultural property. 2018. Available at: http://www.unesco.org/new/fileadmin/MULTIMEDIA/HQ/CLT/movable/pdf/Toolkit_01.pdf Accessed on: 29 Aug. 2020.

$84 \mathrm{KOCH}$, Corine. A blue shield for the protection of our endangered cultural heritage. International Preservation Issues, n. 4, 2003. Available at: https://www.ifla.org/files/assets/pac/ipi/ipi4-e.pdf Accessed on: 29 Aug. 2020.
}

\section{Protection of cultural property: measures}

There are many ways in which cultural property can be protected during international and non-international armed conflict and even during peacetime. Though war in the past had destroyed many cultural properties but if timely action could have been taken the loss to such cultural property could have been mitigated.

\subsection{Transportation of Cultural Property}

This is one of the most effective ways of protecting all movable cultural property like pictures, paintings , idols etc. It is not in doubt that this option will not be able to protect immoveable structures. The transportation of cultural property away from conflict zones will protect cultural property from being subject to attack by high contracting parties. This method will keep cultural property awayfrom the bombardment zone and air strike zone and can keep them safe. All vehicles carrying such cultural property are protected by distinctive emblems and hence not targets of military operations. Article 13 of Hague convention protects transportation of such cultural property ${ }^{85}$. It is an obligation on the high contracting parties to war to prevent exportation of cultural property from occupied state to other places and the occupying state should take custody of cultural property and should return the cultural property to the occupied state once the cessation of hostilities ${ }^{86}$.

\subsection{Fostering the Spirit of Respect for Cultural Property}

There is a need of attempt on part of states to undertake to disseminate awareness about importance of cultural property and also text of cultural property convention can be distributed among everyone so they are aware about laws related to cultural property ${ }^{87}$. Under

\footnotetext{
85 BROSCHE, J. Heritage under attack: motives for targeting cultural property during armed conflict. International Journal of Heritage Studies, 2016. Available at: https://www.diva-portal.org/smash/get/ diva2:1051738/FULLTEXT01.pdf Accessed on: 29 Aug. 2020.

86 RASHID, S. et al. Protection of cultural property in the light of international Humanitarian Law. Journal of Critical Reviews, v. 7, n. 6, 2020. Available at: http://www.jcreview.com/fulltext/197-1588576264.pdf Accessed on: 29 Aug. 2020.

87 KEANE, D. The failure to protect cultural property in wartime. DePaul J. Art, Tech. \& Intell. Prop. L., v. 14, n. 1, 2004.
} 
article 25 Of Hague convention 1954 it is mentioned that convention should be made known to everyone especially armed forces and forces engaged in protection of cultural property. Wider publicity will improve protection status as popular conscience of people can extend a far reaching protection of cultural property ${ }^{88}$.

\subsection{Special Protection and Enhanced Protection for cultural property}

The cultural properties of importance all around the globe have been registered under the register of cultural property under special protection. All the cultural properties should be marked with distinctive emblem that is blue shield for cultural property (Article 10 Hague Convention on cultural property 1954$)^{89}$. Cultural property should at any time shall never be use for military purposes like shortage of weapon or using premises of such cultural property to plan and direct attack or take part in hostilities ${ }^{90}$. International Committee for Protection of Cultural Property explain few conditions to have a enhanced protection regime for cultural property ${ }^{91}$. Three conditions to be fulfilled by cultural property to have a enhanced protection (I) It should be cultural heritage of importance for Mankind (2) It should be recognised and protected by legal and administrative measure at both national as well as international level (3) It is not used for any military purpose and parties to conflict undertakes not to use them for military purposes ${ }^{92}$.

Available at: https://via.library.depaul.edu/coi/viewcontent. cgi?article $=1200 \&$ context=jatip Accessed on: 29 Aug. 2020 .

88 PATEL, K. Culture wars: protection of cultural monuments in a human rights context. Available at: https://studentorgs.kentlaw. iit.edu/jicl/wp-content/uploads/sites/5/2014/01/Patel_Note.pdf Accessed on: 29 Aug. 2020.

89 PATEL, K. Culture wars: protection of cultural monuments in a human rights context. Available at: https://studentorgs.kentlaw. iit.edu/jicl/wp-content/uploads/sites/5/2014/01/Patel_Note.pdf Accessed on: 29 Aug. 2020.

90 MCDONALD, David (ed.). Culture under fire: Armed Non-State actors and Cultural Heritage in wartime. 2018. Available at: https:// genevacall.org/wp-content/uploads/2017/10/Cultural_Heritage_ Study_Final.pdf Accessed on: 29 Aug. 2020.

91 KEEFE, R. The meaning of 'cultural property' under the 1954 Hague Convention. Netherlands International Law Review, n. 46, p. 2656, 1999. Available at: https://www.cambridge.org/core/journals/ netherlands-international-law-review/article/meaning-of-culturalproperty-under-the-1954-hague-convention/D86C46B8F8996D4AB8C4A10D74B5E95D Accessed on: 29 Aug. 2020.

92 HOWE, Z. Can the 1954 Hague Convention apply to nonstate actors? a study of Iraq and Libya. Texas International Law Journal, n. 47, p. 403-425, 2019. Available at: https://www.aiamilitarypanel. org/wp-content/uploads/2019/01/Howe403.pdf Accessed on: 29

\section{Downplaying the factor of military necessity}

Immunity has been provided by the Hague Convention 1954 from attack (Article 9) but this immunity is lifted if property is used for military purpose (Article $11)^{93}$. Military necessity is something which gives military advantage to one party involved in hostilities and also the act which are legal according to laws of war ${ }^{94}$. In practice it has been observed that military necessity is sometimes confused with military convenience ${ }^{95}$. Many parties to conflict do indiscriminate bombardment or attack, which cause a lot of damage to civilian and cultural property. High contracting parties find it easy to do an indiscriminate attack and therefore end up destroying many cultural property ${ }^{96}$. One of the most important principle of International Humanitarian law is principle of proportionality and according to this principle the force used should be directly proportional to the risk or harm estimated ${ }^{97}$. If the principle of proportionality of attack will be followed the damage to cultural property around the globe will decrease. Let's assume that three combatants are hiding at a cultural property and the other party to conflict have an option of attack through missiles and tank but if the high contracting party uses tanks and missiles the entire cultural property will suffer a loss but counter action that can be take in this case is sending you best five or ten soldiers to kill those combatant to force them to surrender $^{98}$. The above hypothetical situation will pro-

Aug. 2020.

93 TIM VAN LIT. Cultural property, war crimes and Islamic State. 2016. Available at: http://iadaa.org/wp-content/uploads/2016/05/Cultural-Property-War-crimes-and-Islamic-State-2016.pdf Accessed on: 29 Aug. 2020.

94 LUIGI, Colonel Postiglione; ARMY, Italian. The protection of Cultural Heritage during Armed Conflicts. Available at: https:/ / publications. armywarcollege.edu/pubs/3482.pdf Accessed on: 29 Aug. 2020.

95 BERENDS, J. Cultural Property Protection Makes sense. Available at: https://www.cimic-coe.org/resources/make-sense-series/culturalproperty-protection-makes-sense.pdf Accessed on: 29 Aug. 2020.

96 ARIMATSU, Louise; CHOUDHURY, Mohbuba. Protecting cultural property in non-international armed conflicts: Syria and Iraq. Int'l L. Stud., v. 91, 2015. Available at: https://digital-commons. usnwc.edu $/$ cgi $/$ viewcontent . cgi?article $=1412 \&$ context $=$ ils Accessed on: 29 Aug. 2020.

${ }^{97}$ WARNER, M. The last poor plunder from a bleeding land: the failure of international law to protect Syrian Antiquities. Brook J. Int'l L., v. 42, 2016. Available at: https://brooklynworks.brooklaw. $\mathrm{edu} / \mathrm{cgi} /$ viewcontent.cgi?article $=1664 \&$ context $=$ bjil Accessed on: 29 Aug. 2020.

98 KREDER, J.; DEGRAAF, K. Museums in the Crosshairs: Un- 
tect cultural property from probable damage that could have caused due to tanks and missiles ${ }^{99}$.

\section{International criminalisation of wrongs against cultural property}

The very first step to criminalize the act of attack on cultural property was first started by the International Criminal Tribunal for Nuremberg. The International Criminal Tribunal at Nuremberg also punished crimes against humanity to those people who were involved in destruction of property of cultural importance . Julius Streicher was found guilty for his crimes and his role in destruction of the Nuremberg Synagogue in 1938 and also for extermination of Jews People ${ }^{100}$.

The second step for criminalizing act of attack on cultural property was first started by International Criminal Tribunal for Yugoslavia, the tribunal is no more functional and stopped all its function in year 2014 but still its past work is of great relevance for protection of cultural property. Under Article 3(d) of ICTY Statute it protects institutions dedicated for religion, charity and education, buildings, Arts and science, historic monuments and other cultural property ${ }^{102}$.

During Yugoslavian war in 1990 the combatants deliberately targeted various cultural properties and destroyed them including UNESCO world heritage listed sites. One of the most important cultural property was Fortified city of Dubrovnik which was targeted in year

intended Consequences of the War on terror. Wash. U. Global Stud. L. Rev., n. 10, 2011. Available at: https://openscholarship.wustl. $\mathrm{edu} /$ cgi $/$ viewcontent.cgi?article $=1018 \&$ context $=$ law_globalstudies Accessed on: 29 Aug. 2020.

99 VRDOLJAK, A. Cultural heritage in buman rights and bumanitarian law. 2009. Available at: http://heritage.sensecentar.org/assets/Uploads/sg-7-12-vrdoljak-heritage-en.pdf Accessed on: 29 Aug. 2020. 100 NUREMBERG trial judgements: Julius Streicher. Available at: https://www.jewishvirtuallibrary.org/nuremberg-trial-judgementsjulius-streicher Accessed on: 29 Aug. 2020.

101 UNITED NATIONS. Criminal tribunal for former Yugoslavia by year's end, residual mechanism will assume remaining workload, its president tells general assembly. 2017. Available at: https://www.un.org/press/ en $/ 2017 /$ ga11963.doc.htm\#: :text=After $\% 2024 \% 20$ years $\% 20$ the $\% 20$ Tribunal,against $\% 20$ impunity $\% 2 \mathrm{C} \% \mathrm{E} 2 \% 80 \% 9 \mathrm{D} \% 20$ he\%20said. Accessed on: 29 Aug. 2020.

102 INTERNATIONAL CRIMINAL TRIBUNAL FOR THE FORMER YUGOSLAVIA. Dubrovnik and Crimes against Cultural Heritage. Available at: https://www.icty.org/en/outreach/documentaries/dubrovnik-and-crimes-against-cultural-heritage Accessed on: 29 Aug. 2020.
1991 and this attack involved Miodrag Jokic a commander of the Yugoslav People's Army and his senior Pavle Struger ${ }^{103}$ who was found to have legal and effective control on the armed forces which was responsible for attack on Dubrovnik ${ }^{104}$. Miodrag Jokić was sentenced to seven years imprisonment by ICTY ${ }^{105}$ and Pavle Strugar was sentenced for eight years imprisonment. In this many important factors like importance of cultural property, when an attack can be directed against cultural property, immunity of cultural property, willful conduct of preparators etc is discussed ${ }^{106}$.

The biggest breakthrough for protection of cultural property can be seen from Rome Statue 1998 which created a hard law with regard to cultural property. The Rome Statuteunder Article 8 defines war crime and extensive destruction of property which is not justified by military necessity and is carried against property unlawfully and wantonly is kind of war crime ${ }^{107}$. The Statute confers jurisdiction to ICC in this matter. Rome's statute also prohibits destroying and seizing enemies property except in case of military necessity. Article 77 of Rome statue talks about forfeiture of proceeds, property and assets derived from crime under this Statute.

International Criminal Court was established under Rome Statue 1998 in year 2002 to punish criminals for war crimes, crime against humanity and Genocide. The International Criminal Court works on principle of complementarity ${ }^{108}$ and exercise jurisdiction in all such

103 INTERNATIONAL CRIMINAL TRIBUNAL FOR THE FORMER YUGOSLAVIA. Judgment in the case of Prosecutor $v$. Pavle Strugar: Pavle Strugar sentenced o eight years imprisonment. Available at: https://www.icty.org/en/press/judgement-case-prosecutorv-pavle-strugar-pavle-strugar-sentenced-eight-years $\%$ E2\%80\%99imprisonment Accessed on: 29 Aug. 2020.

104 VRDOLJAK, A. The criminalisation of the intentional destruction of cultural heritage. 2016. Available at: https://www.ohchr.org/ Documents/Issues/CulturalRights/DestructionHeritage/NGOS/ A.P.Vrdoljak_text1.pdf Accessed on: 29 Aug. 2020.

105 UNITED NATIONS. Prosecutor v. Miodrag Jokic, IT-01-42/1S. Available at: https://www.icty.org/x/cases/miodrag_jokic/tjug/ en/jok-sj040318e.pdf Accessed on: 29 Aug. 2020.

106 VRDOLJAK, A. The criminalisation of the intentional destruction of cultural heritage. 2016. Available at: https://www.ohchr.org/ Documents/Issues/CulturalRights/DestructionHeritage/NGOS/ A.P.Vrdoljak_text1.pdf Accessed on: 29 Aug. 2020.

107 INTERNATIONAL CRIMINAL COURT. Rome Statute of the International Criminal Court. Available at: https://www.icc-cpi.int/ resource-library/documents/rs-eng.pdf Accessed on: 29 Aug. 2020. 108 INTERNATIONAL CENTER FOR TRANSITIONAL JUSTICE. What is Complementarity? National Courts, the ICC, and the Struggle against Impunity. Available at: https://www.ictj.org/sites/ default/files/subsites/complementarity-icc/ Accessed on: 29 Aug. 
cases when a state which has ratified the Rome Statute is unwilling or unable to punish a criminal for war crime ${ }^{109}$ , crime against humanity ${ }^{110}$ and Genocide ${ }^{111}$. One such landmark decision of cultural property by ICC is in the case of Ahmad Al Faqi Al Mahdi who was a member of radical Islamic group and committed various acts of war crimes including destruction of cultural property during occupation of Timbuktu in 2012. He was charged for war for attacking 10 religious, historic buildings and monuments. All the property which was attacked by Al Mahdi were listed as world heritage sites and was under UNESCO protection ${ }^{112}$. AL Mahndi was punished for 9 years in imprisonment under concept of individual criminal responsibility by ICC and was sentenced on 27 September 2016 by Trail Chamber VIII for war crime of intentionally attacking and targeting cultural property in Timbuktu, Mali in June and July $2012^{113}$. International Criminal Court has shown the world that if someone destroys Cultural property he will be punished and create a percent for other no to do what AL Mahdi has done in Timbuktu, Mali ${ }^{114}$. Punishing people for Individual Criminal Responsibility for war crimes will yield desirable results of deterrence and universal acceptance of norm of protection of cultural property and also universal condemnation of any attack against cultural property ${ }^{115}$.

2020 .

109 COLBY, Elbridge. War Crimes and their punishment. Minnesota Law Review, p. 40-46, 1924. Available at: https://core.ac.uk/download/pdf/217206027.pdf Accessed on: 29 Aug. 2020.

110 ROBERTS, Christopher. On the definition of crimes against humanity and other widespread or systematic human rights violations. Journal of Law and Social Change, 2017. Available at: https://scholarship.law.upenn.edu/cgi/viewcontent. cgi?article $=1202 \&$ context $=$ jlasc Accessed on: 29 Aug. 2020 .

111 CUPIDO, Marjolein. The contextual embedding of genocide: a casuistic analysis of the interplay between law and facts. Melbourne Journal of International Law, n. 15, 2014. Available at: https:/ /aw.unimelb.edu.au/_data/assets/pdf_file/0008/1586879/Cupido1.pdf Accessed on: 29 Aug. 2020.

112 STERIO, M. Individual criminal responsibility for the destruction of religious and historic buildings: the al mahdi case. Case $W$. Res. J. Int'l L., v. 49, n. 1, 2017. Available at: https://scholarlycommons.law.case.edu $/$ cgi $/$ viewcontent.cgi?article $=2500 \&$ context $=$ jil Accessed on: 29 Aug. 2020.

113 Anissa Barrak, Ahmad Al Faqi Al Mahdi: 'I plead guilty' (October- December 2017), https://en.unesco.org/courier/2017-october-december/ahmad-al-faqi-al-mahdi-i-plead-guilty

114 INTERNATIONAL CRIMINAL COURT. Ahmad Al Faqi Mahdi transferred to UK prison facility to serve sentence. 2019. Available at: https://www.icc-cpi.int/Pages/item.aspx?name=pr1451 Accessed on: 29 Aug. 2020.

115 INTERNATIONAL CRIMINAL COURT. Abmad Al Faqi Mahdi transferred to UK prison facility to serve sentence. 2019. Available at:
10 Conclusion

There is an element of emotional attachment in case of cultural property which is not so in case of other properties. The implications of destruction or spoiling of such property are serious in nature and impacts the social fiber. However the response of International Humanitarian Law has been good and the probable reasons for violation can be traced back to the non legal factors and not to the discrepancies of International Humanitarian Law. The international community has jointly shown concern pertaining to the protection of the cultural property and the concern has increased specifically after Gulf War and Yugoslavian conflicts, which has in turn resulted in enacting of statutes and protocols. It cannot be however denied that the efficacy of such laws is more upon the acceptance received from the global community.

The International Humanitarian Law pertains to the basic values of humanitarianism and that of multiculturalism when we talk about the development pertaining to protection of cultural property and we have observed a shift from territoriality to that of common cultural property. There have been strict measures in order to enhance safeguard levels and the policy of dealing with the hostilities against cultural property are more stringent and it is need of the hour that these developments are supported by solidarity from international community, awareness and education regarding preserving of the culture and of preserving civilization and the nations should implement the said policies in their domestic laws.

Right to cultural property is group rights and belongs to the whole mankind. No individual, state or government should destroy any cultural property whatsoever. Also the issue as to whether and under what circumstances the UN Security Council may take security measures under Article 39 is a controversial one.

Destruction of cultural property is also taken care of by national legislation and almost all countries have some sort of legislation to punish people and groups for destruction of cultural property. Wanton distraction of many cultural properties we have seen in recent past especially the Destruction of Buddha Statues by Taliban Forces and loss of such an important cultural

https://www.icc-cpi.int/Pages/item.aspx?name=pr1451 Accessed on: 29 Aug. 2020. 
property due to fundamentalism ${ }^{116}$. Many terrorist and rebel groups use cultural property as a means to bargain for recognition at international level and sometimes also attract the world towards them and their works. For Non-International armed conflict and terrorists attack damaging cultural property many municipal laws are there which prevent theft, misappropriation and attack on any cultural property and municipal system of different states are sufficient to check destruction of cultural property at national level. Protecting cultural property in International armed conflict becomes tricky because of involvement of two high contracting parties ${ }^{117}$. The states now may not invoke their sovereignty and domestic jurisdiction for justifying the acts of deliberate destruction of Cultural Property which have great importance for humanity.

The acts of destruction of cultural property and loss of vital heritage have been seen to occur as a consequence of Iconoclasm or effects of armed conflicts. Iconoclasm has been used as a military tactic to demoralize people of one particular religion or ethnicity. The practice or tactic of Iconoclasm is a very old concept and can be dated back to hundreds of years. There have been many instances as mentioned in this paper as to when this tactic was adopted.

International Criminal Court has worked on principle of complementarity ${ }^{118}$ and it has time and again demonstrated that if anyone tries to destroy cultural property then punishment shall be inflicted and the International Criminal court plays a vital role in dealing with the instances of destruction of the cultural properties. Stringent punishments can be imposed by the International Criminal Courts to ensure that the deliberate acts of destruction of the cultural properties are stopped.

The protection of cultural property when seen at

\footnotetext{
116 FRANCIONI, Francesco; LENZERINI Federico. The destruction of the Buddhas of Bamiyan and international law. Available at: http: / $/$ www.ejil.org $/$ article.php?article $=436 \&$ issue $=27 \quad$ Accessed on: 29 Aug. 2020.

117 FRANCIONI, Francesco; LENZERINI Federico. The destruction of the Buddhas of Bamiyan and international law. Available at: http: / $/$ www.ejil.org/article.php?article $=436 \&$ issue $=27 \quad$ Accessed on: 29 Aug. 2020.

118 INTERNATIONAL CENTER FOR TRANSITIONAL JUSTICE. What is Complementarity? National Courts, the ICC, and the Struggle against Impunity. Available at: https://www.ictj.org/sites/ default/files/subsites/complementarity-icc/ Accessed on: 29 Aug. 2020 .
}

the international level from the angle of Public International Law has acquired more of a human dimension in the $21^{\text {st }}$ century. Public International Law has been changing constantly so as to take into its purview the emerging challenges that have sought to demonstrate human dimension for protection of cultural properties but at the same time taking into consideration the fact that state is the central factor for protecting the cultural property. However the power of the States is limited from the pressure of the international community and also common interests through international obligations and the jurisdiction of the states is further restricted by the act of individuals and groups.

Hence in order to ensure the protection of the cultural properties it is imminent that there is ratification of all the treaties which will further ensure that there is global acceptance to the fact that the cultural property needs to be preserved and protected and also recognition as to the fact that any act of destruction of these cultural properties is equivalent to attack on the identity of people. It will also lead to recognition that it is vital to have a sense of respect for the culture and cultural property of everyone and it will also apply to the states to ensure respect for their own cultural property and that of other states and groups. The ratification will also ensure the universal recognition and application for the emblems of the cultural property in armed conflict. The states should be able to take part in the international institutions so as to protect the cultural property and the cultural properties of great importance should be identified. There is also a need of a joint effort on part of all the states to come together to ensure protection of cultural properties and share the experience pertaining to the measures adopted for protection of cultural property. Training sessions are organized by most of the nations for their armed forces to provide training in International Humanitarian Law and it is crucial that this training should also include training pertaining to protection of cultural property and what all measures should be adopted in order to ensure the same and also the sites which shelter the cultural properties should not be in vicinity of the military objectives. The cultural rights defenders and human rights defenders who actively voice for protection of cultural rights also play a vital role and more recognition should be given to these people ${ }^{119}$.

119 BENNOUNE, K. Report of Special Rapporteur in the field of cultural rights. Available at: https:// documents-dds-ny.un.org/doc/UN- 
The protection of cultural properties does not only apply to the states but also the individuals who have rights and obligations towards the protection of property. It is also upon the individuals to ensure protection of the cultural property and hence an active role can be played by the individuals and the groups in order to protect the cultural heritage. A collective effort is required by the global community for coordination among states and also among individuals and various groups.

\section{References}

ARIMATSU, Louise; CHOUDHURY, Mohbuba. Protecting cultural property in non-international armed conflicts: Syria and Iraq. Int'l L. Stud., v. 91, 2015. Available at: https://digital-commons.usnwc.edu/cgi/ viewcontent.cgi? article $=1412 \&$ context $=$ ils Accessed on: 29 Aug. 2020.

AVALON PROJECT. The Lieber Code. 1863. Available at: https://avalon.law.yale.edu/19th_century/lieber. asp\#sec2 Accessed on: 29 Aug. 2020.

BENNOUNE, K. Report of Special Rapporteur in the field of cultural rights. Available at: https://documents-ddsny.un.org/doc/UNDOC/GEN/N20/207/39/PDF/ N2020739.pdf?OpenElement Accessed on: 29 Aug. 2020.

BERENDS, J. Cultural Property Protection Makes sense. Available at: https://www.cimic-coe.org/resources/ make-sense-series/cultural-property-protection-makessense.pdf Accessed on: 29 Aug. 2020.

BHAT, P. Protection of cultural property under international bumanitarian law: some emerging trends. 2001. Available at http://www.commonlii.org/in/journals/ ISILYBIHRL/2001/4.html Accessed on: 29 Aug. 2020.

BOOHER, Alice A. The military advantage: the military. com guide to military and veterans benefits. Available at: https://www.bva.va.gov/docs/VLR_VOL2/ Copy12--AliceBooher.pdf Accessed on: 29 Aug. 2020.

BROSCHE, J. Heritage under attack: motives for targeting cultural property during armed conflict. International Journal of Heritage Studies, 2016. Available at: https:/ / www.diva-portal.org/smash/get/diva2:1051738/
FULLTEXT01.pdf Accessed on: 29 Aug. 2020.

CENTER FOR THE ENVIRONMENTAL MANAGEMENT OF MILITARY LANDS. Types of Cultural Property. Available at: https://www.cemml.colostate. edu/cultural/09476/chp04-02iraqenl.html Accessed on: 29 Aug. 2020.

CHETTRY, Aniket Tathagat. Unravelling the myth exploring state and religin under aurangzeb. Glob J Arch \& Anthropol, n. 6, 2018. Available at: https://juniperpublishers.com/gjaa/GJAA.MS.ID.555686.php Accessed on: 29 Aug. 2020.

COLBY, Elbridge. War Crimes and their punishment. Minnesota Law Review, p. 40-46, 1924. Available at: https://core.ac.uk/download/pdf/217206027.pdf Accessed on: 29 Aug. 2020.

COMMISSION INTERNATIONALE DE JURISTES. The question of Tibet and the rule of law. 1959. Available at: http://www.icj.org/wp-content/uploads /1959/01/Tibet-rule-of-law-report-1959-eng.pdf Accessed on: 29 Aug. 2020.

CULTURAL Heritage. Available at: https://www.peacepalacelibrary.nl/research-guides/special-topics/cultural-heritage/ Accessed on: 29 Aug. 2020.

CUNLIFFE, Emma et al. The destruction of cultural property in the Syrian Conflict: legal implications and obligations. International Journal of Cultural Property, n. 23, p. 1-31, 2016. Available at: https://www.cambridge.org/core/journals/international-journal-of-culturalproperty/article/destruction-of-cultural-property-inthe-syrian-conflict-legal-implications-and-obligations / 5B81E9C84C7F9B24FA0C4F1E9FA50CAF/ core-reader Accessed on: 29 Aug. 2020.

CUPIDO, Marjolein. The contextual embedding of genocide: a casuistic analysis of the interplay between law and facts. Melbourne Journal of International Law, n. 15, 2014. Available at: https://law.unimelb.edu.au/_data/ assets/pdf_file/0008/1586879/Cupido1.pdf Accessed on: 29 Aug. 2020.

DALE, Catherine. Operation Iraqi freedom: strategies, approaches, results and issues of congress. 2009. Available at: https://fas.org/sgp/crs/natsec/RL34387.pdf Accessed on: 29 Aug. 2020. 
ELSNER, Jas. Iconoclasm as discourse: from antiquity to Byzantium. The Art Bulletin, n. 94, p. 368-394, 2012. Available at: https://www.jstor.org/stable/23268277 Accessed on: 29 Aug. 2020.

FLIPPO, R. Attacks against cultural property as a weapon of war: an exploratory case study. Available at: https:// www.ibei.org/ibei_studentpaper34_105354.pdf Accessed on: 29 Aug. 2020.

FORSYTH, Marion. Casualties of war: the destruction of Iraq's cultural heritage as a result of U.S. action during and after the 1991 Gulf War. DePaul J. Art, Tech. \& Intell. Prop. L., v. 14, 2004. Available at: https://via.library.depaul.edu/cgi/viewcontent.cgi?referer=https:/ / www.google.com $/ \&$ httpsredir=1\&article $=1202 \&$ conte xt=jatip Accessed on: 29 Aug. 2020.

FRANCIONI, Francesco; LENZERINI Federico. The destruction of the Buddhas of Bamiyan and international law. Available at: http://www.ejil.org/article. php?article $=436 \&$ issue $=27$ Accessed on: 29 Aug. 2020 .

FREEDBERG, D. Art and Iconoclasm, 1525-1580, the case of the Northern Netherlands. Available at: http://www.columbia.edu/cu/arthistory/faculty/Freedberg/Art-andIconoclasm.pdf Accessed on: 29 Aug. 2020.

GENERAL COUNSEL OF THE DEPARTAMENT OF DEFENSE. Department of Defense Law of War Manual. 2015. Available at: https://dod.defense.gov/Portals / 1 /Documents / pubs / DoD \%20Law $\% 20$ of $\% 20$ War\%20Manual\%20-\%20June\%202015\%20Updated $\% 20 D e c \% 202016 . p d f ? v e r=2016-12-13-172036-190$ Accessed on: 29 Aug. 2020.

GERMANY. Treaty of Peace with Germany (Treaty of Versailles). Available at: https://www.loc.gov/law/help/ustreaties/bevans/m-ust000002-0043.pdf Accessed on: 29 Aug. 2020.

GERSTENBLITH, Patty. The destruction of cultural heritage: a crime against property or a crime against people? J. Marshall Rev. Intell. Prop. L., n. 15, 2016. Available at: https://repository.jmls.edu/cgi/viewcontent. cgi? article $=1382 \&$ context $=$ ripl Accessed on: 29 Aug. 2020 .

HARVARD LAW SCHOOL. Art in time of war: pillage, plunder, repression, reparations and restitution. Available at: http://www.law.harvard.edu/faculty/ martin/art_law/war.htm\#: : :text $=$ places $\% 20$ of $\% 20$ worship-, Without $\% 20$ prejudice $\% 20$ to $\% 20$ the $\% 20$ pro- visions $\% 20$ of $\% 20$ the $\% 20$ Hague $\% 20$ Convention $\% 20$ for, the $\% 20$ cultural $\% 20$ or $\% 20$ spiritual $\% 20$ heritage Accessed on: 29 Aug. 2020.

HAYASHI, Nobuo. Requirements of military necessity in international humanitarian law and international criminal law. Boston University International Law Journal, n. 28, p. 41-139, 2010. Available at: https:/ / www.bu.edu/law/ journals-archive/international/documents/39-140.pdf Accessed on: 29 Aug. 2020.

HENCKAERTS, Jean-Marie; DOSWALD-BECK, Louise. Customary International Humanitarian Law. New York: Cambridge University Press, 2005. Available at: https://www.icrc.org/en/doc/assets / files/other/customary-international-humanitarian-law-i-icrc-eng.pdf Accessed on: 29 Aug. 2020.

HERODOTUS. Herodotus: on the customs of the persians. 2012. Available at: https://www.ancient.eu/article/149/herodotus-on-the-customs-of-the-persians / Accessed on: 29 Aug. 2020.

HOWE, Z. Can the 1954 Hague Convention apply to non-state actors? a study of Iraq and Libya. Texas International Law Journal, n. 47, p. 403-425, 2019. Available at: https://www.aiamilitarypanel.org/wp-content/ uploads/2019/01/Howe403.pdf Accessed on: 29 Aug. 2020.

ICCROM. Protecting cultural heritage in times of conflict. Available at: https://www.iccrom.org/sites/default/files/ICCROM_18_ProtectingHeritageConflict_en.pdf Accessed on: 29 Aug. 2020.

ICONOCLASTS Battle. Available at: https://scannerfasr942.weebly.com/iconoclasts-battle-1.html Accessed on: 29 Aug. 2020.

INTERNATIONAL CENTER FOR TRANSITIONAL JUSTICE. What is Complementarity? National Courts, the ICC, and the Struggle against Impunity. Available at: https://www.ictj.org/sites/default/files/ subsites/complementarity-icc/ Accessed on: 29 Aug. 2020 .

INTERNATIONAL COMMITTEE OF THE RED CROSS. Rule 38, ICRC on customary IHL. Available at: https://ihl-databases.icrc.org/customary-ihl/eng/ docs/v1_rul_rule38 Accessed on: 29 Aug. 2020.

INTERNATIONAL COMMITTEE OF THE RED CROSS. Rule 40, ICRC on customary IHL. Available at: https://ihl-databases.icrc.org/customary-ihl/eng/ 
docs/v2_rul_rule40 Accessed on: 29 Aug. 2020.

INTERNATIONAL COMMITTEE OF THE RED CROSS. Treaty on the Protection of Artistic and Scientific Institutions and Historic Monuments, (April 15, 1935). Available at: https://ihl-databases.icrc.org/ihl/ INTRO/325?OpenDocument Accessed on: 29 Aug. 2020.

INTERNATIONAL CRIMINAL COURT. Abmad Al Faqi Mahdi transferred to UK prison facility to serve sentence. 2019. Available at: https://www.icc-cpi.int/Pages/item. aspx?name=pr1451 Accessed on: 29 Aug. 2020.

INTERNATIONAL CRIMINAL COURT. Rome Statute of the International Criminal Court. Available at: https:/ / www.icc-cpi.int/resource-library/documents/rs-eng. pdf Accessed on: 29 Aug. 2020.

INTERNATIONAL CRIMINAL TRIBUNAL FOR THE FORMER YUGOSLAVIA. Dubrounik and Crimes against Cultural Heritage. Available at: https://www. icty.org/en/outreach/documentaries/dubrovnik-andcrimes-against-cultural-heritage Accessed on: 29 Aug. 2020.

INTERNATIONAL CRIMINAL TRIBUNAL FOR THE FORMER YUGOSLAVIA. Judgment in the case of Prosecutor v. Pavle Strugar: Pavle Strugar sentenced o eight years imprisonment. Available at: https://www.icty.org/ en/press/judgement-case-prosecutor-v-pavle-strugarpavle-strugar-sentenced-eight-years $\%$ E2\%80\%99-imprisonment Accessed on: 29 Aug. 2020.

ISAKHAN, Benjamin; ZARANDONA, Jose Antonio Gonzalez. Destroying Mosul's Great Mosque: Islamic State's symbolic war to the end. 2014. Available at: https:/ theconversation.com/destroying-mosuls-great-mosqueislamic-states-symbolic-war-to-the-end-80002 Accessed on: 29 Aug. 2020.

KASTENBERG, Joshua E. The legal regime for protecting cultural property during armed conflict. Air Force Law Review, n. 42, 1997. Available at: https://digitalrepository.unm.edu/cgi/viewcontent. cgi?article $=1423 \&$ context $=$ law_facultyscholarship Accessed on: 29 Aug. 2020.

KEANE, D. The failure to protect cultural property in wartime. DePaul J. Art, Tech. \& Intell. Prop. L., v. 14, n. 1, 2004. Available at: https://via.library.depaul.edu/cgi/ viewcontent. . gi? article $=1200 \&$ context $=$ jatip Accessed on: 29 Aug. 2020.
KEEFE, R. The meaning of 'cultural property' under the 1954 Hague Convention. Netherlands International Law Review, n. 46, p. 26-56, 1999. Available at: https://www.cambridge.org/core/journals/netherlands-international-law-review/article/meaning-ofcultural-property-under-the-1954-hague-convention / D86C46B8F8996D4AB8C4A10D74B5E95D Accessed on: 29 Aug. 2020.

$\mathrm{KOCH}$, Corine. A blue shield for the protection of our endangered cultural heritage. International Preservation Issues, n. 4, 2003. Available at: https:/ /www.ifla.org/files/ assets/pac/ipi/ipi4-e.pdf Accessed on: 29 Aug. 2020.

KOSSIAKOFF, Megan. The art of war: the protection of cultural property during the "Siege" of Sarajevo(1992-95). DePaul Journal of Art, Technology and Intellectual Property Law, v. 14, 2004. Available at: https://via.library.depaul.edu/cgi/viewcontent. cgi?article $=1203 \&$ context $=$ jatip Accessed on: 29 Aug. 2020.

KREDER, J.; DEGRAAF, K. Museums in the Crosshairs: Unintended Consequences of the War on terror. Wash. U. Global Stud. L. Rev., n. 10, 2011. Available at: https://openscholarship.wustl.edu/cgi/viewcontent. cgi? article $=1018 \&$ context $=$ law_globalstudies Accessed on: 29 Aug. 2020.

LASSON, Kenneth. Incitement in the Mosques: testing the limits of free speech and religious liberty. Whittier L. Rev., n. 27, 2005. Available at: https:// scholarworks.law.ubalt.edu/cgi/viewcontent. cgi?article $=1384 \&$ context $=$ all_fac Accessed on: 29 Aug. 2020.

LEMKIN, R. Acts constituting a general (transnational) danger considered as offences against the law of nations. 1993. Available at: http://www.preventgenocide.org/lemkin/madrid1933-english.htm Accessed on: 29 Aug. 2020.

LUIGI, Colonel Postiglione; ARMY, Italian. The protection of Cultural Heritage during Armed Conflicts. Available at: https://publications.armywarcollege.edu/pubs/3482. pdf Accessed on: 29 Aug. 2020.

MACAULEY-LEWIS, Elizabeth. The history of art and architecture in the islamic world. Available at: https:// brewminate.com/the-history-of-art-and-architecturein-the-islamic-world/ Accessed on: 29 Aug. 2020.

MALI, accountability for the destruction of cultural heritage. Available at: https://casebook.icrc.org/case- 
study/mali-accountability-destruction-cultural-heritage Accessed on: 29 Aug. 2020.

MARKING of cultural property with emblems of the 1954 Hague Convention. Available at: https://www. cemml.colostate.edu/cultural/09476/chp04-10egyptenl.html Accessed on: 29 Aug. 2020.

MCDONALD, David (ed.). Culture under fire: Armed Non-State actors and Cultural Heritage in wartime. 2018. Available at: https://genevacall.org/wp-content/ uploads/2017/10/Cultural_Heritage_Study_Final.pdf Accessed on: 29 Aug. 2020.

MEZEY, Naomi. The paradoxes of cultural property. Colum. L. Rev., n. 107, p. 2004-2046, 2007. Available at: https://scholarship.law.georgetown.edu/cgi/viewcontent.cgi?article $=1902 \&$ context $=$ facpub Accessed on: 29 Aug. 2020.

MILLIGAN, A. Targeting cultural property: the role of international law. Available at: https://jpia.princeton. edu/sites/jpia/files/2008-5.pdf Accessed on: 29 Aug. 2020 .

MORGAN, L. The Buddhas of Bamiyan. Cambridge, Massachusetts: Harvard University Press, 2012. Available at: www.jstor.org/stable/j.ctt2jbt4h, Accessed on: 29 Aug. 2020.

MOSE, Gregory M. The destruction of churches and mosques in Bosnia- Herzegovina: seeking a rightsbased approach to the protection of religious cultural property. Buffalo Journal of International Law, n. 3, 1996. Available at: https://digitalcommons.law.buffalo.edu/ cgi $/$ viewcontent.cgi?article $=1028 \&$ context $=$ bjil Accessed on: 29 Aug. 2020.

MOUSTAKAS, J. Group rights in cultural property: justifying strict inalienability. Cornell Law Review, n. 74, 1989. Available at: https://core.ac.uk/download/ pdf/216738239.pdf Accessed on: 29 Aug. 2020.

MYEROWITZ, Elissa S. Protecting cultural property during a time of war: why Russia should return nazilooted art. Fordham International Law Journal, n. 20, 1996. Available at: https://ir.lawnet.fordham.edu/cgi/ viewcontent.cgi? referer=https:/ / www.google.com/\& httpsredir $=1 \&$ article $=1808 \&$ context $=$ ilj Accessed on: 29 Aug. 2020.

NUREMBERG trial judgements: Julius Streicher. Available at: https://www.jewishvirtuallibrary.org/nuremberg-trial-judgements-julius-streicher Accessed on: 29
Aug. 2020.

OLD Testament. Available at: https://www.catholic. org/bible/old_testament.php Accessed on: 29 Aug. 2020.

OPEN SOCIETY JUSTICE INITIATIVE. Abmad $A l$ Faqi Al Mabdi at the ICC. 2016. Available at: https:// www.justiceinitiative.org/publications/ahmad-al-faqial-mahdi-icc Accessed on: 29 Aug. 2020.

PARVEN, Alam. Temple Destruction and the Great Mughals religious policy in North India: a case study of Banaras Region. Analisa Journal of Social Science and Religion, p. 1526-1707. Available at: https://pdfs. semanticscholar.org/3210/fdc936fa3a055c9005aa43de48448edef18a.pdf Accessed on: 29 Aug. 2020.

PATEL, K. Culture wars: protection of cultural monuments in a human rights context. Available at: https:/ / studentorgs.kentlaw.iit.edu/jicl/wp-content/uploads/ sites/5/2014/01/Patel_Note.pdf Accessed on: 29 Aug. 2020 .

PAVLOVIC, Srda. The siege of Dubrovnik and the consequences of the 'Warfor peace'. 2009. Available at: https://pescanik.net/ the-siege-of-dubrovnik-and-the-consequencesof-the-war-for-peace/ Accessed on: 29 Aug. 2020.

PETROVIC, Drazen. Ethnic cleansing: an attempt at methodology. 1994. Available at: http://www.ejil.org/ pdfs/5/1/1247.pdf Accessed on: 29 Aug. 2020.

POSNER, Eric A. The international protection of cultural property: some skeptical observations. Chicago Journal of International Law, n. 8, 2007. Available on https://core.ac.uk/download/pdf/190354673.pdf Accessed on: 29 Aug. 2020.

RASHID, S. et al. Protection of cultural property in the light of international Humanitarian Law. Journal of Critical Reviews, v. 7, n. 6, 2020. Available at: http://www. jcreview.com/fulltext/197-1588576264.pdf Accessed on: 29 Aug. 2020.

RICHARD, Lieutenant Colonel Theodore T. Nuclear weapons targeting: the evolution of law and U.S. Policy, Military Law Review, v. 224, n. 4, 2016. Available at: https://www.loc.gov/rr/frd/Military_Law/Military_ Law_Review/pdf-files/224-issue4-2016.pdf Accessed on: 29 Aug. 2020.

ROBERTS, Christopher. On the definition of crimes against humanity and other widespread or systematic human rights violations. Journal of Law and Social Change, 
2017. Available at: https://scholarship.law.upenn.edu/ cgi $/$ viewcontent. cgi article $=1202 \&$ context $=j$ lasc Accessed on: 29 Aug. 2020.

SAAVEDRA, Beatriz Wrtinez. Shaping the 'Community': Hindu Nationalist Imagination in Gujarat, 1880-1950. Available at: http://wrap.warwick.ac.uk/57285/7/ WRAP_THESIS_Martinez-Saavedra_2013.pdf Accessed on: 29 Aug. 2020.

SANDHAR, J. Cultural genocide in Tibet: the failure of article 8 of the United Nations Declaration on the Rights of Indigenous Peoples in protecting the cultural rights of Tibetans. Santander Art and Culture Law Review, v. 2, n. 1, 2015. Available at: https://www.ejournals.eu/ SAACLR/2015/2(2015)/art/6788/ Accessed on: 29 Aug. 2020.

SAUTMAN, B. Tibet and the (Mis-) representation of cultural genocide. Available at: https://link.springer.com/content/pdf/10.1057\%2F9780230601192_6.pdf Accessed on: 29 Aug. 2020.

SCHLUESSEL, Eric Tanner. The muslim emperor of China: everyday politics in colonial Xinjiang, 1877-1933. 2016. Thesis (Doctor of Philosophy) - Harvard University, Cambridge, 2016. Available at: https://dash.harvard. edu/bitstream/handle/1/33493602/SCHLUESSELDISSERTATION-2016.pdf Accessed on: 29 Aug. 2020.

SHERWIN, R. Law, metaphysics, and the new iconoclasm. Law Text Culture, n. 11, p. 70-105, 2007. Available at: https://ro.uow.edu.au/cgi/viewcontent. cgi? article $=1040 \&$ context $=$ ltc Accessed on: 29 Aug. 2020.

STERIO, M. Individual criminal responsibility for the destruction of religious and historic buildings: the al mahdi case. Case W. Res. J. Int'l L., v. 49, n. 1, 2017. Available at: https://scholarlycommons.law.case.edu/cgi/ viewcontent. cgi? article $=2500 \&$ context $=$ jil Accessed on: 29 Aug. 2020.

STEWART, D. Why did God order the destruction of the Canaanites? Available at: https://www.blueletterbible.org/ faq/don_stewart/don_stewart_1382.cfm Accessed on: 29 Aug. 2020.

THE HAGUE Rules of Air Warfare. 1922. Available at: https://wwi.lib.byu.edu/index.php/The_Hague_Rules_of_Air_Warfare Accessed on: 29 Aug. 2020.
THURLOW, Matthew D. Protecting cultural property in Iraq: how american military policy comports with international law. Yale Hum. RTS \& DEV. L. J., n. 8, 2005. Available at: https://digitalcommons.law.yale.edu/cgi/ viewcontent.cgi?article $=1050 \&$ context $=$ yhrdlj Accessed on: 29 Aug. 2020.

TIM VAN LIT. Cultural property, war crimes and Islamic State. 2016. Available at: http://iadaa.org/wp-content/ uploads/2016/05/Cultural-Property-War-crimes-andIslamic-State-2016.pdf Accessed on: 29 Aug. 2020.

U.S. COMMITTEE OF THE BLUE SHIELD. Laws and Treaties protecting cultural property: 1874 Brussels Declaration. Available at: https://uscbs.org/1880-oxfordmanual.html Accessed on: 29 Aug. 2020.

UNESCO. Convention for the protection of cultural property in the event of armed conflict with regulations for the execution of the convention 1954. Available at: http://portal.unesco.

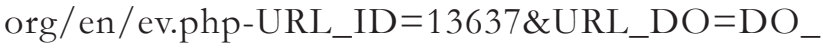
TOPIC\&URL_SECTION=201.html Accessed on: 29 Aug. 2020.

UNESCO. Protection of cultural property. Available at: http://www.unesco.org/new/fileadmin/MULTIMEDIA/HQ/CLT/pdf/MilitaryManuel-En.pdf Accessed on: 29 Aug. 2020.

UNESCO. The fight against the illicit trafficking of cultural objects the 1970 convention: past and future. Available at: http://www.unesco.org/new/fileadmin/MULTIMEDIA/HQ/CLT/pdf/2013_INFOKIT_1970_EN.pdf Accessed on: 29 Aug. 2020.

UNITED NATIONS EDUCATIONAL, SCIENTIFIC AND CULTURAL ORGANIZATION. Fighting the Illicit Trafficking of cultural property. 2018. Available at: http://www.unesco.org/new/fileadmin/MULTIMEDIA/HQ/CLT/movable/pdf/Toolkit_01.pdf Accessed on: 29 Aug. 2020.

UNITED NATIONS. Criminal tribunal for former Yugoslavia by year's end, residual mechanism will assume remaining workload, its president tells general assembly. 2017. Available at: https://www.un.org/press/en/2017/ga11963. doc.htm\#: : text=After $\% 2024 \% 20$ years $\% 20$ the $\% 20$ Tribunal,against $\% 20 \mathrm{impunity} \% 2 \mathrm{C} \% \mathrm{E} 2 \% 80 \% 9 \mathrm{D} \% 20$ he\%20said. Accessed on: 29 Aug. 2020. 
UNITED NATIONS. Prosecutor v. Miodrag Jokic, IT01-42/1-S. Available at: https://www.icty.org/x/cases/ miodrag_jokic/tjug/en/jok-sj040318e.pdf Accessed on: 29 Aug. 2020.

UNITED NATIONS. United Nations Declaration on the rights of Indigenous Peoples. Available at: https://www. un.org/development/desa/indigenouspeoples/wpcontent/uploads/sites/19/2018/11/UNDRIP_E_ web.pdf Accessed on: 29 Aug. 2020.

VRDOLJAK, A. Cultural heritage in buman rights and bumanitarian law. 2009. Available at: http:// heritage.sensecentar.org/assets/Uploads/sg-7-12-vrdoljak-heritageen.pdf Accessed on: 29 Aug. 2020.

VRDOLJAK, A. The criminalisation of the intentional destruction of cultural heritage. 2016. Available at: https:// www.ohchr.org/Documents/Issues/CulturalRights/ DestructionHeritage/NGOS/A.P.Vrdoljak_text1.pdf Accessed on: 29 Aug. 2020.
WANGKEO, K. Monumental challenges: the lawfulness of destroying cultural heritage during peacetime. The Yale Journal of International Law, v. 28, p. 183-274, 2003. Available at: https://digitalcommons.law.yale. edu/cgi/viewcontent.cgi?article $=1206 \&$ context $=$ yjil Accessed on: 29 Aug. 2020.

WARNER, M. The last poor plunder from a bleeding land: the failure of international law to protect Syrian Antiquities. Brook J. Int'l L., v. 42, 2016. Available at: https://brooklynworks.brooklaw.edu/cgi/viewcontent. cgi?article $=1664 \&$ context $=$ bjil Accessed on: 29 Aug. 2020.

WEGNER, Emma. "Hagia Sophia, 532-37.”2004. Available at: http://www.metmuseum.org/toah/hd/haso/ hd_haso.htm Accessed on: 29 Aug. 2020.

ZHANG YUE. Customary International Law and the Rule against taking cultural property as spoils of war. Chinese Journal of International Law, v. 17, p. 943-989, 2018. Available at: https://academic.oup.com/chinesejil/article-pdf/17/4/943/27275819/jmy030.pdf Accessed on: 29 Aug. 2020. 
Para publicar na Revista de Direito Internacional, acesse o endereço eletrônico www.rdi.uniceub.br ou www.brazilianjournal.org.

Observe as normas de publicação, para facilitar e agilizar o trabalho de edição. 